\title{
Marine atmospheric boundary layer over some Southern Ocean fronts during the IPY BGH 2008 cruise
}

\author{
C. Messager ${ }^{1}$, S. Speich ${ }^{1}$, and E. Key ${ }^{2}$ \\ ${ }^{1}$ Laboratoire de Physique des Océans, CNRS, UMR 6523, BP 70, 29280 Plouzané Cedex, France \\ ${ }^{2}$ National Science Foundation, Office of Polar Programs, 4201 Wilson Blvd, Arlington, VA, 22230, USA \\ Correspondence to: C. Messager (christophe.messager@ifremer.fr)
}

Received: 8 March 2012 - Published in Ocean Sci. Discuss.: 28 March 2012

Revised: 14 September 2012 - Accepted: 29 September 2012 - Published: 23 November 2012

\begin{abstract}
A set of meteorological instruments was added to an oceanographic cruise crossing the Southern Ocean from Cape Town to $57^{\circ} 33^{\prime} \mathrm{S}$ during the summer of 2008 . The Cape Cauldron, the Subtropical, Subantarctic, Polar and southern Antarctic Circumpolar current fronts were successively crossed. The recorded data permitted to derive the exchange of momentum, heat and water vapour at the oceanatmosphere interface. A set of 38 radiosonde releases complemented the dataset. The marine atmospheric boundary layer characteristics and air-sea interaction when the ship crossed the fronts and eddies are discussed.

The specific role of the atmospheric synoptic systems advection on the air-sea interaction over these regions is highlighted.

Additionally, the Subantarctic front mesoscale variability induced an anticyclonic eddy considered as part of the Subantarctic front. The specific influence of this Agulhas ring on the aloft atmosphere is also presented.
\end{abstract}

\section{Introduction}

Several in-situ observational studies have previously identified some interactions between the Sea Surface Temperature (SST) and the atmosphere over regions where intensive and highly variable mesoscale activity is persistent: Gulf Stream and Kuroshio and Agulhas currents (Businger and Shaw, 1984; Jury and Walker, 1988; Friehe et al., 1991; Rouault and Lee-Thorp, 1996; Kwon et al., 1998; Giordani et al., 1998; Rouault and Lutjeharms, 2000; Rouault et al., 2000a, b; Bourras et al., 2004; Tokinaga et al., 2006). These papers described the SST fronts' interaction with the atmo- sphere and wind changes near the surface and throughout the Marine Atmospheric Boundary Layer (MABL). The past decade of satellite observations have permitted an improved understanding of the relationship between SST and surface winds at oceanic mesoscales over many regions. The review of these interactions, in-situ, remotely and numerically identified, can be found in Chelton et al. (2004), Xie (2004) and Small et al. (2008). The SST fronts are supposed to interact with the aloft atmosphere through the dynamic (wind variability) and thermodynamic effects; both induce changes in the vertical structure of the MABL. For instance, Small et al. (2008) showed that air-sea interactions are enhanced in the vicinity of oceanic frontal regions. The air-sea surface differences induce changes in the vertical structure of the MABL which is mainly controlled by both pressure gradients and the turbulent mixing of momentum as air flows across a front. The atmospheric vertical potential temperature profile is expected to be stabilized (or neutrally stabilized) over the cold front side and destabilized over the warm front side. This and substantial changes in turbulent heat fluxes across ocean fronts can give rise to some changes in boundary layer structure and height. In some cases, an Internal Boundary Layer (IBL) is formed as air flows across a front. Moreover, differential heating of the MABL across an ocean front tends to create a pressure gradient force in the direction of the SST gradient. The effect on the MABL is to increase (decrease) the wind stress over warm (cold) water through a modification of the vertical structure of the MABL by turbulent heat fluxes.

For the specific case of the wind magnitude changes above SST discontinuities both in-situ and remote (satellite) measurements were used. For the latter, the interaction was 


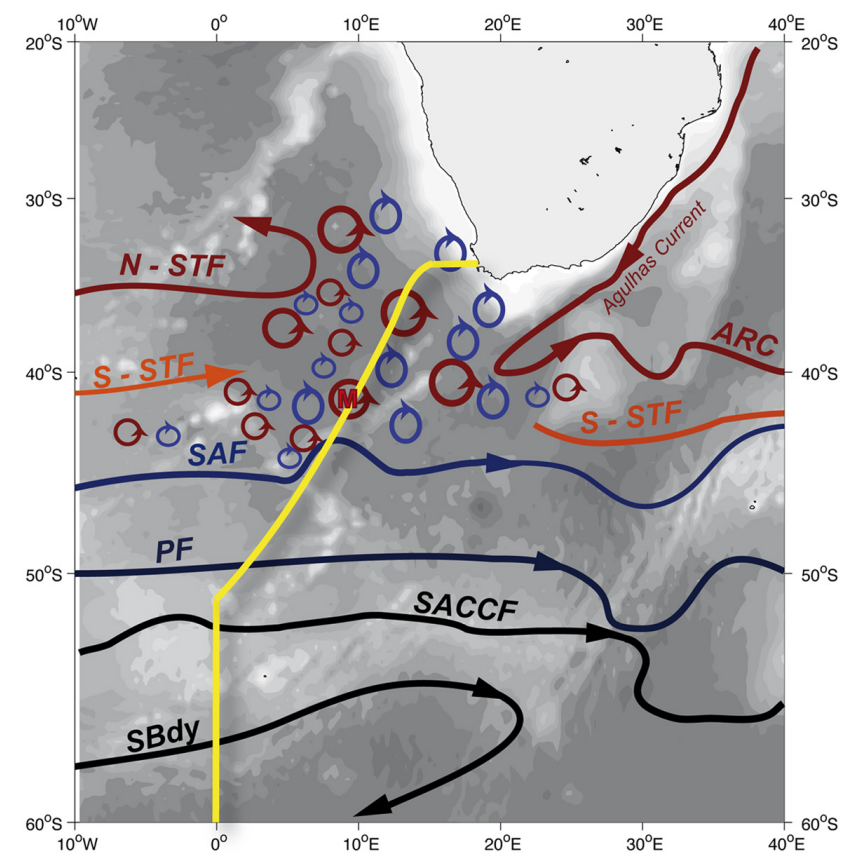

Fig. 1. Front locations (for the period 15 February-20 March 2008) based on satellite altimetry. ARC is the Agulhas Return Current; NSTF and S-STF are the Norhern and the Southern Subtropical Front (STF) respectively; SAF is the Subantarctic Front, PF is the Polar Front, SACCF is the Southern ACC front and SBy is the Southern Boundary. Also shown are the ship track (yellow line) and the location of the "M" eddy (see text).

highlighted by averaging surface data over weeks in order to reduce the effects of powerful synoptic weather feature variability that can hide less energetic signals due to sea surface discontinuities. Such an approach is thus more climatic than related to process investigation. However, the SST-wind interaction was also highlighted with in-situ observation but only when synoptic weather conditions were fair enough (wind not exceeding $15 \mathrm{~m} \mathrm{~s}^{-1}$, whatever the location of the in-situ campaigns) and thus, when the MABL structure was rather affected by the predominant local effect. Small et al. (2008) actually mentioned that the SST-MABL interaction description is complicated by the displacement of synoptic atmospheric features and these are expected to play an important role in the setting of the vertical stratification. However, once the MABL vertical structure variability is considered, the magnitude and the importance of the MABL diurnal cycle is then also questionable. Indeed, the latter drives the vertical mixing when synoptic conditions are fair over many Earth places.

All these interaction processes were mainly investigated in the Northern Hemisphere western boundary current system (e.g., Kwon et al., 2010; Kelly et al., 2010); less is known about the Southern Ocean (SO) frontal system and its effect on the atmosphere. The main feature of the SO is its conspicuous frontal banding (i.e., Orsi et al., 1995; Belkin and Gordon, 1996). The SO is limited to the north by the Southern Subtropical Front (S-STF), which separates subtropical and subantarctic waters. To the south of it flows the Antarctic Circumpolar Current (ACC) which consists of multiple branches and filaments that are gathered to represent the main ACC fronts (Swart et al., 2008; Sokolov and Rintoul, 2009a, b). The fronts often exhibit considerable latitudinal variability on their circumpolar path. These forms of variability are dominant in the mesoscale induced by front meandering and eddy genesis (Lutjeharms and Valentine, 1988; Stammer, 1998; Phillips and Rintoul, 2000; Morrow et al., 2004).

The S-STF also marks the southern limit of the Agulhas current, which transports warm water along the southeastern coast of Africa and which is regarded as the strongest western boundary current in the Southern Hemisphere and the largest of the world's oceans (Bryden et al., 2005). South of Africa, its retroflexion, the Agulhas Retroflection, has a large impact on climate, regional weather and marine ecosystems (Lutjeharms, 2006). This powerful current produces meanders, which eject many persistent eddies (Lutjeharms and van Ballegooyen, 1988; Boebel et al., 2003). The eddies, fronts, and filaments associated with the Agulhas Current and Retroflexion are numerous and spread with sharp horizontal SST gradients. These surface discontinuities impact the air-sea exchanges locally and regionally (Jury and Walker, 1988; LeeThorp et al., 1999; Rouault and Lutjeharms, 2000; Reason, 2001; Small et al., 2008).

The hydrographic structure and frontal systems between Africa and Antarctica have been studied and described (e.g., Lutjeharms and Valentine, 1984; Belkin and Gordon, 1996; Swart et al., 2008; Gladyshev et al., 2008) but little work was conducted to better understand the regional and temporal variability of the SO fronts south of Africa (Sokolov and Rintoul, 2009a; Swart and Speich, 2010). Ever since, the specific issues related to the SO south of Africa versus atmospheric dynamics have been poorly documented. However, within the Agulhas Current system, north of the S-STF, the response of the MABL to a SST gradient has already been described by Walker and De Mey (1988), De Mey et al. (1990) or Rouault et al. (1995). A more spatially spread study (Rouault and Lee-Thorp, 1996) described measurements of the MABL between Cape Town and Marion Island. However, no atmospheric campaign crossed successively the Cape Basin, the S-STF (covering the western subtropical convergence windward the Agulhas Retroflection area), or any of the ACC fronts. This latter region has thus a poor set of ocean-atmosphere measurements compared to other regions around the world, despite its importance for the climate and the global warming exchanges between the Indian and the Atlantic oceans as well as with the atmosphere (Lutjeharms, 2006). Also, the literature does not bring any information about the air-sea intraction issue for locations south of the South African S-STF. 
The international GoodHope program was undertaken in 2004 to monitor the exchange of water and properties between the Atlantic and Indian oceans, and to better understand the processes involved in these exchanges (e.g., Ansorge et al., 2004). The 2008 cruise of the GoodHope program was carried out in the framework of the International Polar Year, and was named the BONUS-GoodHope cruise (hereafter BGH), since it associated the fourth hydrographic sampling of the GoodHope line with atmospheric and biogeochemical measurements constitutive of the BONUS program. The BGH cruise followed the track presented in Fig. 1 and crossed successively the Cape Basin, the STF and the ACC fronts. Starting from Cape Town in South Africa (13 February 2008), the R/V Marion Dufresne sailed southwest to reach the Greenwich line, at which it sailed southward until $57^{\circ} 33^{\prime} \mathrm{S}$ (18 March 2008). The BGH cruise was an opportunity to perform some atmospheric measurements over these regions where in-situ data are rare due to severe weather conditions (much of the regional history has been derived from satellite retrievals). It was the first time this section was instrumented with atmospheric measurements in order to have surface information as well as the vertical structure of the MABL through the regular releases of radiosondes (see Sect. 3). These measurements also allowed the computation of surface fluxes. A large set of meteorological data was continuously sampled in order to describe the atmosphere close to the surface while crossing remarkable ocean features (fronts, eddies).

The aim of this paper is thus to present the set of atmospheric observations performed during the BGH cruise. Moreover, this work presents a highlight of the relative influence of the frontal SST anomaly effect (Sect. 4), the synoptic features effect (Sect. 5) as well as the MABL diurnal cycle effect (Sect. 6) on the observed sea surface-atmosphere interaction when the ship met oceanic southern fronts and eddies.

\section{Ocean dynamics and fronts}

The BGH route was planned to maximize sampling of the complex oceanic temperature fields, which included shortlived filaments, mesoscale eddies, and SO fronts. The regional upper-ocean structure, together with the frontal locations, is shown in Fig. 1, where fronts are drawn using satellite altimetry (Swart and Speich, 2010; Arhan et al., 2011), and Argo float data (Faure et al., 2011). However, their precise locations mentioned hereafter are determined using the hydrographic data collected during the survey and classical hydrographic criteria (e.g., Orsi et al., 1995; Belkin and Gordon, 1996) (see also Fig. 2).

Compared with Drake Passage and south of Australia, the oceanic sector south of Africa constitutes the most dynamic and variable sector of the SO. The Agulhas Current, which lies along the southeastern edge of the African continental shelf, is marked by a region of extreme mesoscale variability (Lutjeharms, 2006) in the form of eddy shedding that is associated with the current retroflecting back toward the east (Gordon, 1985; Duncombe-Rae, 1991; Lutjeharms, 1996; de Ruijter et al., 1999; Boebel et al., 2003). The Agulhas Retroflection region is characterized by an intermittent stream of anticyclones (Agulhas Rings) and cyclones (Lutjeharms and Gordon, 1987; de Ruijter et al., 1999). The rings are occluded from the Agulhas Retroflection, propagate generally in a northwest direction (Schouten et al., 2000), then intersecting the GoodHope line in the subtropical domain (Gladyshev et al., 2008; Swart et al., 2008).

The ACC is characterized by a series of eastward jets associated with baroclinic fronts, which denote the positions of the maximum meridional thermohaline gradients (e.g., Orsi et al., 1995; Belkin and Gordon, 1996). In the African sector of the SO, four primary fronts exist: the Southern Subtropical Front (S-STF), the Subantarctic Front (SAF), the Polar Front $(\mathrm{PF})$, and the southern ACC front (SACCF). Additionally, the southern boundary of the ACC (SBdy) marks the limit separating flow between the ACC and Weddell Gyre system (Orsi et al., 1993). The spatial structure of the S-STF south of Africa is complicated by the presence of Agulhas Rings, particularly in the region of the BGH line, in the Cape Basin. At this location, the S-STF is made up by an almost continual "stream" of eddies (Lutjeharms and Valentine, 1988; Belkin and Gordon, 1996; Dencausse et al., 2010). Because of this complex subtropical-subantarctic transition at the south of Africa, the detection of the S-STF led to a wide latitudinal span, from $38^{\circ} 20^{\prime} \mathrm{S}$ to $42^{\circ} \mathrm{S}$, suggestive of two branches at these latitudes during the BGH cruise. The northern limit of this interval shows the most pronounced gradient (e.g.: a SST drop of $5{ }^{\circ} \mathrm{C}$ and salinity change from 34.7 to 35.0 , at $100 \mathrm{~m}$ ), and lies at the southern border of the wide saline domain $(S>35.0)$ marking the border of an Agulhas ring (Arhan et al., 2011). The northern branch of the S-STF was crossed on the 24 February (day 55 since the 1 January 2008). The southern limit of the S-STF coincides with the southern border of an Agulhas cyclone that was shed 4.5 months before from the Agulhas Banc (Arhan et al., 2011). This cyclone so-called "S eddy" - was crossed the 26 February (day 57) from $40.6^{\circ} \mathrm{S}$ to $42.5^{\circ} \mathrm{S}$ while one of the southern type of Agulhas Rings - so called "M-eddy" - was crossed just north of the SAF, from $42.7^{\circ} \mathrm{S}$ to $44^{\circ} \mathrm{S}$, during the 28 and $29 \mathrm{Febru}-$ ary (days 59 and 60). This latter ring was 9.5 months old.

The SAF was located at $44.17^{\circ} \mathrm{S}$ and crossed during the 28 and 29 February (day 59 and 60). Following Orsi et al. (1995) the PF was located at the northern end of the domain where a shallow $(<200 \mathrm{~m})$ vertical temperature minimum can be found at $50^{\circ} 22^{\prime} \mathrm{S}$. The PF was thus crossed the 8 March (day 68). The Southern ACC Front (SACCF) location $\left(52^{\circ} 56^{\prime} \mathrm{S}\right)$ was crossed the 12 March (day 72). The Southern Boundary of the ACC (SBdy) was found at $55^{\circ} 54^{\prime} \mathrm{S}$ and crossed on 14 March (day 74). The last BGH station was carried out at $57^{\circ} 33^{\prime} \mathrm{S}$ south of the ACC, in the Weddel Gyre the 16 March. 
Table 1. Instrument characteristics.

\begin{tabular}{|c|c|c|c|c|c|c|}
\hline Manufacturer & Instrument & Height & Parameters & Units & Uncertainty & Sampling rate \\
\hline $\begin{array}{l}\text { Space Science } \\
\text { and Engineering }\end{array}$ & M-AERI & $20 \mathrm{~m}$ & Skin-temperature & ${ }^{\circ} \mathrm{C}$ & $<0.1^{\mathrm{a}}$ & $10 \mathrm{~min}$ \\
\hline $\begin{array}{l}\text { Center, Univer- } \\
\text { sity of Wisconsin- } \\
\text { Madison }\end{array}$ & & & Air temperature & ${ }^{\circ} \mathrm{C}$ & $<0.1^{\mathrm{a}}$ & $10 \mathrm{~min}$ \\
\hline \multirow{5}{*}{$\begin{array}{l}\text { Coastal Envi- } \\
\text { ronmental } \\
\text { Systems Inc. }\end{array}$} & Wind vane 5103 & $20 \mathrm{~m}$ & $\begin{array}{l}\text { Wind speed and di- } \\
\text { rection }\end{array}$ & $\mathrm{ms}^{-1 \circ}$ & $\pm 0.3^{\mathrm{b}} \pm 3^{\mathrm{ob}}$ & $1 \mathrm{~min}$ \\
\hline & Relative & $20 \mathrm{~m}$ & Relative humidity & $\%$ & $\pm 2^{\mathrm{c}}$ & $1 \mathrm{~min}$ \\
\hline & $\begin{array}{l}\text { Humidity } \\
\text { S1057W }\end{array}$ & & & & & \\
\hline & $\begin{array}{l}\text { Barometer } \\
6400\end{array}$ & $20 \mathrm{~m}$ & $\begin{array}{l}\text { Barometric } \\
\text { pressure }\end{array}$ & $\mathrm{hPa}$ & $\pm 0.5^{\mathrm{d}}$ & $1 \mathrm{~min}$ \\
\hline & $\begin{array}{l}\text { Temperature } \\
\text { S1074 }\end{array}$ & & Air temperature & ${ }^{\circ} \mathrm{C}$ & \pm 0.1 & $1 \mathrm{~min}$ \\
\hline \multirow[t]{2}{*}{ Eppley Laboratory } & $\begin{array}{l}\text { Precision Infrared } \\
\text { radiometer }\end{array}$ & $20 \mathrm{~m}$ & Longwave radiation & $\mathrm{W} \mathrm{m}^{-2}$ & $<5 \%$ & $1 \mathrm{~min}$ \\
\hline & $\begin{array}{l}\text { Prescision } \\
\text { Spectral } \\
\text { Pyranometer }\end{array}$ & $20 \mathrm{~m}$ & Shortwave radiation & $\mathrm{W} \mathrm{m}^{-2}$ & $\pm 1 \%$ & $1 \mathrm{~min}$ \\
\hline SeaBird & Thermosalinograph & $-6 \mathrm{~m}$ & $\begin{array}{l}\text { Sea Bulk tempera- } \\
\text { ture }\end{array}$ & ${ }^{\circ} \mathrm{C}$ & \pm 0.01 & $1 \mathrm{~min}$ \\
\hline \multirow[t]{5}{*}{ Vaisälä } & $\begin{array}{l}\text { Radiosondes } \\
\text { RS92-SGP }\end{array}$ & $\begin{array}{l}\text { From } 14 \mathrm{~m} \text { to } \\
29000 \mathrm{~m}\end{array}$ & $\begin{array}{l}\text { Vertical profile of } \\
\text { air temperature }\end{array}$ & ${ }^{\circ} \mathrm{C}$ & $\pm 0.15^{\mathrm{f}}$ & $1 \mathrm{~s}$ to $10 \mathrm{~s}^{\mathrm{g}}$ \\
\hline & & $\begin{array}{l}\text { From } 14 \mathrm{~m} \text { to } \\
29000 \mathrm{~m}\end{array}$ & $\begin{array}{l}\text { Vertical profile of } \\
\text { air humidity }\end{array}$ & $\%$ & $\pm 2 \% \mathrm{f}$ & $1 \mathrm{~s}$ to $10 \mathrm{~s} g$ \\
\hline & & $\begin{array}{l}\text { From } 14 \mathrm{~m} \text { to } \\
29000 \mathrm{~m}\end{array}$ & $\begin{array}{l}\text { Vertical profile of } \\
\text { wind direction }\end{array}$ & $\circ$ & $\pm 2^{\mathrm{f}}$ & $1 \mathrm{~s}$ to $10 \mathrm{~s} g$ \\
\hline & & $\begin{array}{l}\text { From } 14 \mathrm{~m} \text { to } \\
29000 \mathrm{~m}\end{array}$ & $\begin{array}{l}\text { Vertical profile of } \\
\text { wind speed }\end{array}$ & $\mathrm{ms}^{-1}$ & $\pm 0.15^{\mathrm{f}}$ & $1 \mathrm{~s}$ to $10 \mathrm{~s}^{\mathrm{g}}$ \\
\hline & & $\begin{array}{l}\text { From } 14 \mathrm{~m} \text { to } \\
29000 \mathrm{~m}\end{array}$ & $\begin{array}{l}\text { Vertical profile of } \\
\text { barometric pressure }\end{array}$ & $\mathrm{hPa}$ & $\pm 0.4 \mathrm{hPa}$ & $1 \mathrm{~s}$ to $10 \mathrm{~s}^{\mathrm{g}}$ \\
\hline \multicolumn{7}{|c|}{$\begin{array}{l}\text { a Minnett et al. (2001) } \\
\text { b Coastal Environmental Systems, Inc., Wind Monitor } 5103 \text { brochure } \\
\text { c Coastal Environmental Systems, Inc., Relative Humidity Sensor S1057 brochure } \\
\text { d Coastal Environmental Systems, Inc., Barometer } 6400 \text { brochure } \\
\text { e ARM MWR manual for December conditions at the SGP site } \\
\text { f All radiosonde uncertainties are based on repeatability in calibration from Vaisälä }\end{array}$} \\
\hline
\end{tabular}

\section{Data}

A total of 111 hydrographic profiles were obtained at 79 geographical stations, from the African continental slope to beyond the ACC Southern Boundary along the Greenwich Meridian. Further information on the various measurements may be found in the cruise report (Speich and Dehairs, 2008), and details of the hydrographic measurements in the Conductivity-Temperature-Depth (CTD) data report (Branellec et al., 2010).
The atmospheric data were collected by classical atmospheric measurements as well as radiometric and radiosounding processes. The set of instruments was composed by a standard weather station (the Weatherpack) modified for sea application; an interferometer and a radiosonde station (see Table 1).

Most of the instruments except the radiosonde receiver were installed above the footbridge at $20 \mathrm{~m}$ height. Attention was paid to limit the effect of the ship on each instrument, which included profiling and imaging, as well as 
Table 2. Times and locations of the 38 radiosondes released.

\begin{tabular}{|c|c|c|c|c|c|c|}
\hline Sondes & Date & Day/1 Jan & Time & Latitude & Longitude & Information \\
\hline $\mathrm{RS} 1$ & 23 Feb 2008 & 54 & $16: 21$ & $38.09^{\circ} \mathrm{S}$ & $12.09^{\circ} \mathrm{E}$ & \multirow{2}{*}{ STF } \\
\hline $\mathrm{RS} 2$ & 24 Feb 2008 & 55 & $11: 45$ & $39.19^{\circ} \mathrm{S}$ & $11.32^{\circ} \mathrm{E}$ & \\
\hline RS3 & 24 Feb 2008 & 55 & 18:02 & $39.56^{\circ} \mathrm{S}$ & $11.06^{\circ} \mathrm{E}$ & \\
\hline RS4 & 25 Feb 20085 & 56 & $11: 50$ & $40.72^{\circ} \mathrm{S}$ & $10.21^{\circ} \mathrm{E}$ & \\
\hline RS5 & 25 Feb 2008 & 56 & $17: 59$ & $41.18^{\circ} \mathrm{S}$ & $9.92^{\circ} \mathrm{E}$ & \\
\hline RS6 & 26 Feb 2008 & 57 & $11: 55$ & $42.04^{\circ} \mathrm{S}$ & $9.27^{\circ} \mathrm{E}$ & \\
\hline RS7 & 26 Feb 2008 & 57 & $17: 57$ & $42.25^{\circ} \mathrm{S}$ & $9.10^{\circ} \mathrm{E}$ & \\
\hline RS8 & 26 Feb 2008 & 57 & $23: 55$ & $42.47^{\circ} \mathrm{S}$ & $8.93^{\circ} \mathrm{E}$ & \multirow[t]{4}{*}{ Diurnal cycle at a stopped station } \\
\hline RS9 & 27 Feb 2008 & 58 & $06: 12$ & $42.47^{\circ} \mathrm{S}$ & $8.93^{\circ} \mathrm{E}$ & \\
\hline RS10 & 27 Feb 2008 & 58 & $11: 55$ & $42.47^{\circ} \mathrm{S}$ & $8.93^{\circ} \mathrm{E}$ & \\
\hline RS11 & 27 Feb 2008 & 58 & $17: 56$ & $42.47^{\circ} \mathrm{S}$ & $8.93^{\circ} \mathrm{E}$ & \\
\hline RS12 & 28 Feb 2008 & 59 & $11: 55$ & $42.78^{\circ} \mathrm{S}$ & $8.67^{\circ} \mathrm{E}$ & \multirow{3}{*}{ SAF } \\
\hline RS13 & $28 \mathrm{Feb} 2008$ & 59 & $19: 55$ & $43.32^{\circ} \mathrm{S}$ & $8.24^{\circ} \mathrm{E}$ & \\
\hline RS14 & 29 Feb 2008 & 60 & 08:01 & $44.04^{\circ} \mathrm{S}$ & $7.63^{\circ} \mathrm{E}$ & \\
\hline RS15 & 1 Mar 2008 & 61 & $16: 04$ & $44.90^{\circ} \mathrm{S}$ & $6.89^{\circ} \mathrm{E}$ & \\
\hline RS16 & 3 Mar 2008 & 63 & $11: 55$ & $46.36^{\circ} \mathrm{S}$ & $5.54^{\circ} \mathrm{E}$ & \\
\hline RS17 & 4 Mar 2008 & 64 & $12: 05$ & $47.51^{\circ} \mathrm{S}$ & $4.41^{\circ} \mathrm{E}$ & \\
\hline RS18 & 5 Mar 2008 & 65 & $17: 58$ & $47.55^{\circ} \mathrm{S}$ & $4.38^{\circ} \mathrm{E}$ & \\
\hline RS19 & 6 Mar 2008 & 66 & $11: 59$ & $47.97^{\circ} \mathrm{S}$ & $3.96^{\circ} \mathrm{E}$ & \\
\hline $\mathrm{RS} 20$ & 7 Mar 2008 & 67 & $11: 53$ & $49.03^{\circ} \mathrm{S}$ & $2.83^{\circ} \mathrm{E}$ & \\
\hline RS21 & 6 Mar 2008 & 68 & $18: 13$ & $50.11^{\circ} \mathrm{S}$ & $1.61^{\circ} \mathrm{E}$ & \multirow[b]{2}{*}{$\mathrm{PF}$} \\
\hline $\mathrm{RS} 22$ & 9 Mar 2008 & 69 & $12: 14$ & $50.64^{\circ} \mathrm{S}$ & $0.86^{\circ} \mathrm{E}$ & \\
\hline $\mathrm{RS} 23$ & 10 Mar 2008 & 70 & $11: 56$ & $51.85^{\circ} \mathrm{S}$ & $0.00^{\circ} \mathrm{E}$ & \multirow[t]{4}{*}{ Diurnal cycle at a stopped station } \\
\hline $\mathrm{RS} 24$ & 10 Mar 2008 & 70 & $17: 54$ & $51.86^{\circ} \mathrm{S}$ & $0.00^{\circ} \mathrm{E}$ & \\
\hline $\mathrm{RS} 25$ & 10 Mar 2008 & 70 & $23: 55$ & $51.86^{\circ} \mathrm{S}$ & $0.00^{\circ} \mathrm{E}$ & \\
\hline $\mathrm{RS} 26$ & 11 Mar 2008 & 71 & 06:07 & $51.88^{\circ} \mathrm{S}$ & $0.01^{\circ} \mathrm{E}$ & \\
\hline RS27 & 11 Mar 2008 & 71 & $11: 55$ & $51.89^{\circ} \mathrm{S}$ & $0.00^{\circ} \mathrm{E}$ & \multirow{3}{*}{ SACCF } \\
\hline RS28 & 12 Mar 2008 & 72 & $11: 55$ & $52.98^{\circ} \mathrm{S}$ & $0.00^{\circ} \mathrm{E}$ & \\
\hline RS29 & 12 Mar 2008 & 72 & $17: 57$ & $53.26^{\circ} \mathrm{S}$ & $0.00^{\circ} \mathrm{E}$ & \\
\hline RS30 & 13 Mar 2008 & 73 & $11: 55$ & $54.71^{\circ} \mathrm{S}$ & $0.07^{\circ} \mathrm{W}$ & \\
\hline RS31 & 14 Mar 2008 & 74 & $12: 04$ & $55.67^{\circ} \mathrm{S}$ & $0.03^{\circ} \mathrm{E}$ & \\
\hline RS32 & 15 Mar 2008 & 75 & $05: 58$ & $56.74^{\circ} \mathrm{S}$ & $0.00^{\circ} \mathrm{E}$ & \\
\hline RS33 & 15 Mar 2008 & 75 & $17: 51$ & $57.55^{\circ} \mathrm{S}$ & $0.04^{\circ} \mathrm{W}$ & \\
\hline RS34 & 15 Mar 2008 & 75 & $23: 54$ & $57.55^{\circ} \mathrm{S}$ & $0.04^{\circ} \mathrm{W}$ & \\
\hline RS35 & 16 Mar 2008 & 76 & $05: 53$ & $57.55^{\circ} \mathrm{S}$ & $0.04^{\circ} \mathrm{W}$ & \\
\hline RS36 & 16 Mar 2008 & 76 & $11: 55$ & $57.55^{\circ} \mathrm{S}$ & $0.04^{\circ} \mathrm{W}$ & \\
\hline RS37 & 16 Mar 2008 & 76 & $17: 53$ & $57.55^{\circ} \mathrm{S}$ & $0.04^{\circ} \mathrm{W}$ & \\
\hline RS38 & 17 Mar 2008 & 77 & $11: 56$ & $57.55^{\circ} \mathrm{S}$ & $0.04^{\circ} \mathrm{W}$ & \\
\hline
\end{tabular}

those which required adequate ventilation and clear linesof-sight. On the forward railing, to the starboard side of the centreline, two tabs were welded to allow a secure deployment of the Weatherpack and radiation sensors on a T-frame. The Weatherpack provided minute-averaged measurements with a Young anemometer (for wind speed and direction) as well as with sensors to measure air temperature, relative humidity and barometric pressure. They were mounted at the top of the "T". The Eppley pyranometer and pyrgeometer dedicated to longwave and shortwave radiations recording (minute-averaged) were placed on gimbals at the end of each arm of the "T". The plates which house the meteorological measurements were well-ventilated to ensure the best quality data. The Eppley domes were maintained daily to remove traces of precipitation and soot from the ship's smokestack. The two gimbals reduced the effect of ship motion, particularly pitch and roll, on the measurements. Dome temperatures were recorded for the pyrgeometer during the cruise and used in post-processing to ensure the highest accuracy longwave measurement. 


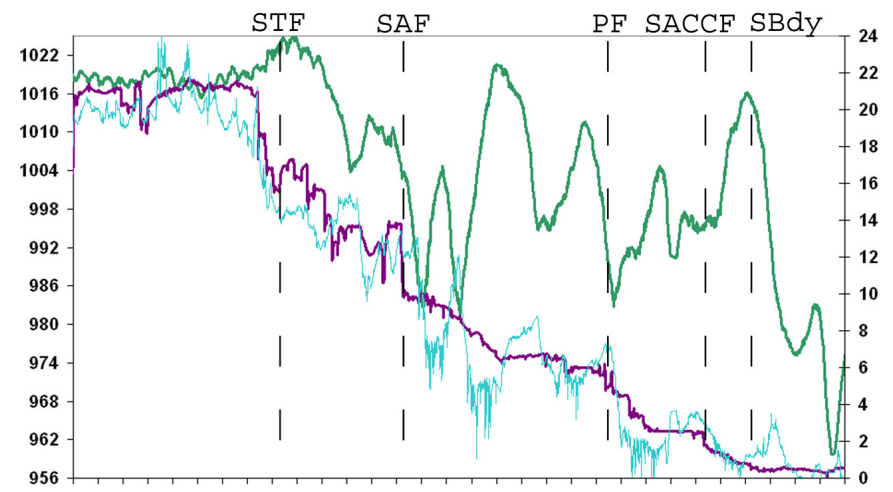

a) 4748495051525354555657585960616263646566676869707

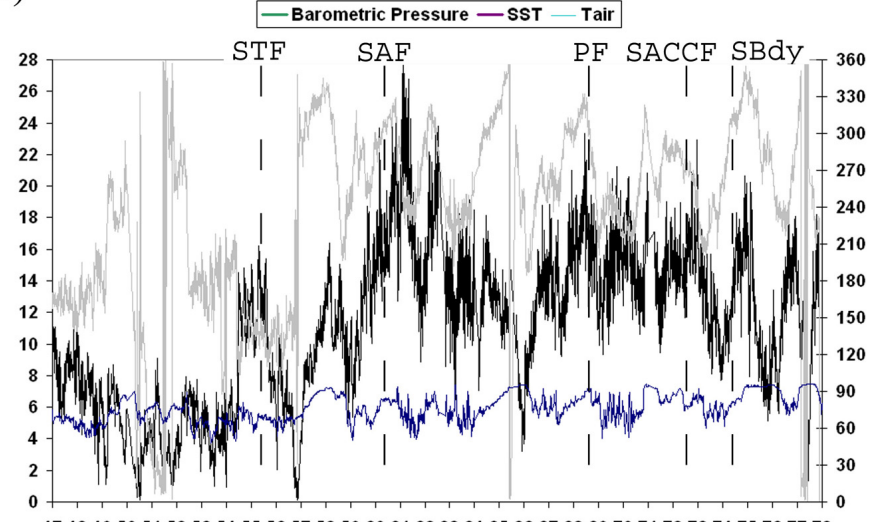

b)

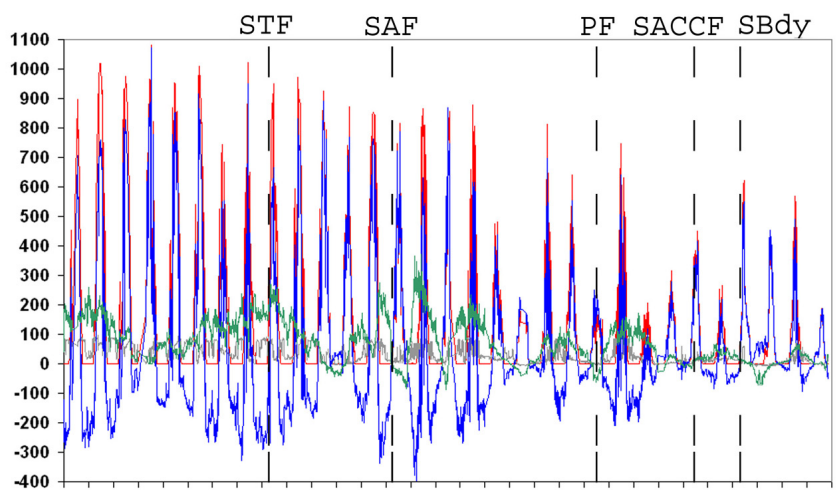

c) 4748495051525354555657585960616263646566676869707172737475767778

Fig. 2. Time series of: (a) the barometric pressure in hPa (green line), the SST and air temperature at ten meters height in ${ }^{\circ} \mathrm{C}$ (purple and blue lines respectively); (b) wind speed in $\mathrm{m} \mathrm{s}^{-1}$ and wind direction (black and grey lines respectively) as well as relative humidity (dark blue line) in \%; (c) turbulent heat fluxes (green curve) - positive upward, incoming solar radiation (red curve) - positive downward, longwave radiation (gray curve) - positive upward, net heat flux (dark blue curve) - negative upward. For (a), left vertical axis is pressure in hPa and right vertical scale is temperature in ${ }^{\circ} \mathrm{C}$. For (b), left vertical axis is wind speed in $\mathrm{m} \mathrm{s}^{-1}$ and right vertical axe is direction in degree as well as relative humidity in $\%$. For (c), vertical axis is heat flux in $\mathrm{W} \mathrm{m}^{-2}$. For all the frames, the horizontal axis is the day number after the 1 January 2008. The vertical dashed black lines are the location of the oceanic fronts.

Along the leg, 38 radiosondes were released providing vertical profiles of the Marine Atmospheric Boundary Layer (MABL) in relation to ocean features. All the radiosondes used were the Vaisälä RS92-SGP starting at $14 \mathrm{~m}$ above sea surface reaching up to between $5000 \mathrm{~m}$ and $29000 \mathrm{~m}$, measuring temperature, humidity, wind speed, wind direction and pressure along a vertical profile following radiosonde ascension. Each sounding was calibrated using a ground-check unit before launch. The soundings were released with preference towards 12:00 UTC and 18:00 UTC. Some were also released irregularly; either at 00:00, 06:00, 12:00 or 18:00 UTC when fronts or eddies were encountered. Additionally, two diurnal cycles were sampled during two long stations (cf. Speich and Dehairs, 2008) at a fixed location. The sounding locations and times of release are presented in Table 2. The sampling frequency for all sounding variables was $10 \mathrm{~s}$ before 4 March 2008 and one second afterwards.

An interferometer, the M-AERI (Marine-Atmospheric Emitted Radiance Interferometer) which measures infrared spectra between 3-18 $\mu \mathrm{m}$ was sited on the starboard railing, with clear fields of view of the sea surface and of the sky overhead. Its measurement cycle includes two blackbody calibration views, as well as views of zenith, and $\pm 55^{\circ}$, which combined take approximately $10 \mathrm{~min}$ to complete. Spectra collected from each view are used to calculate the air temperature and sea surface skin temperature with very high accuracy (deduced from the 7.7 and $14.1 \mu \mathrm{m}$ channels). During times of snow, spray, or rain, the instrument is taped to protect the sensitive electronics inside and to prevent against degradation of the mirror surface.

The Sea Bird thermosalinograph bulk temperature was used as the bulk SST measurement at $6 \mathrm{~m}$ depth with a sampling rate of $1 \mathrm{~min}$. The CTD data were used to control and periodically calibrate the thermosalinograph.

The surface measurements for the entire cruise are presented in Fig. 2, while Figs. 3 and 4 present the potential temperature/relative humidity vertical profiles and the vertical 


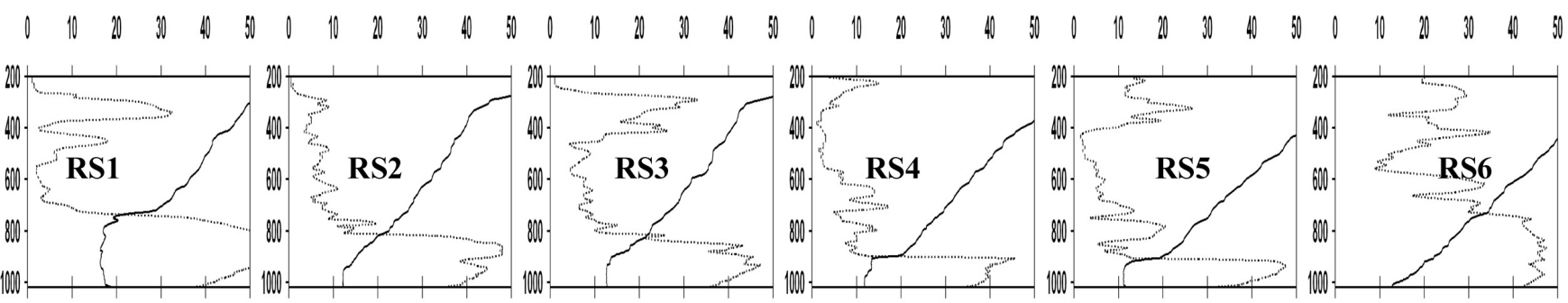

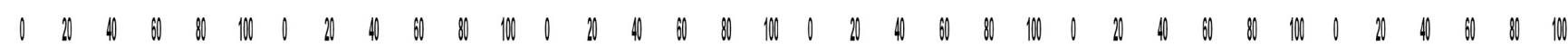

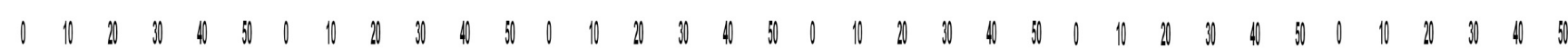
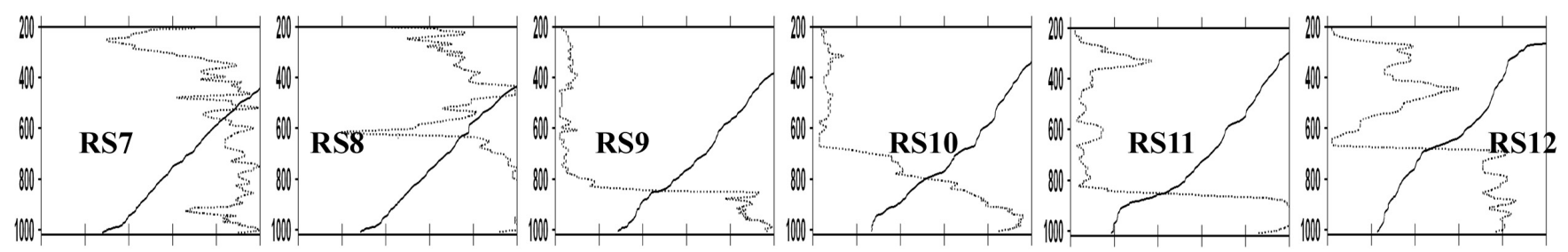

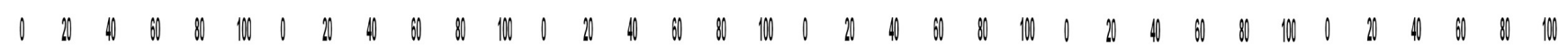

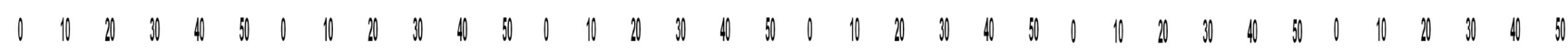
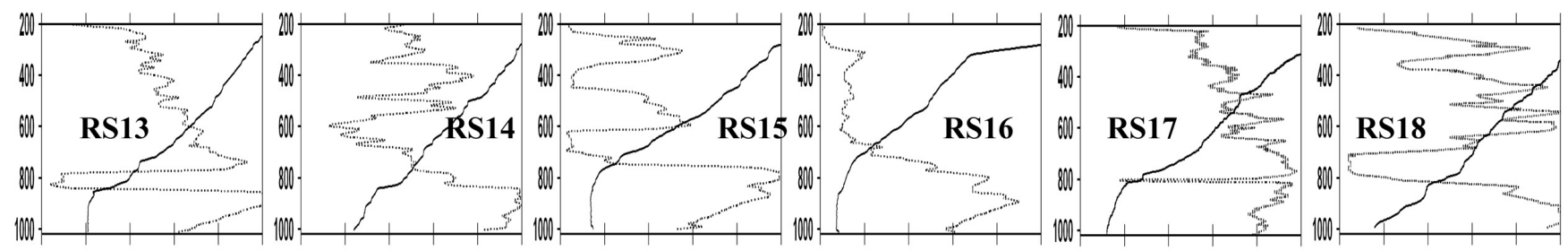

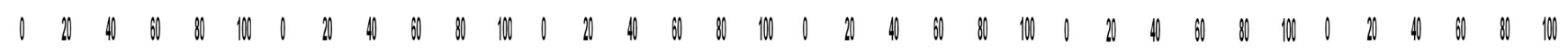

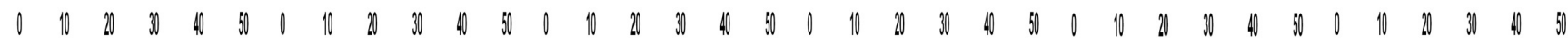
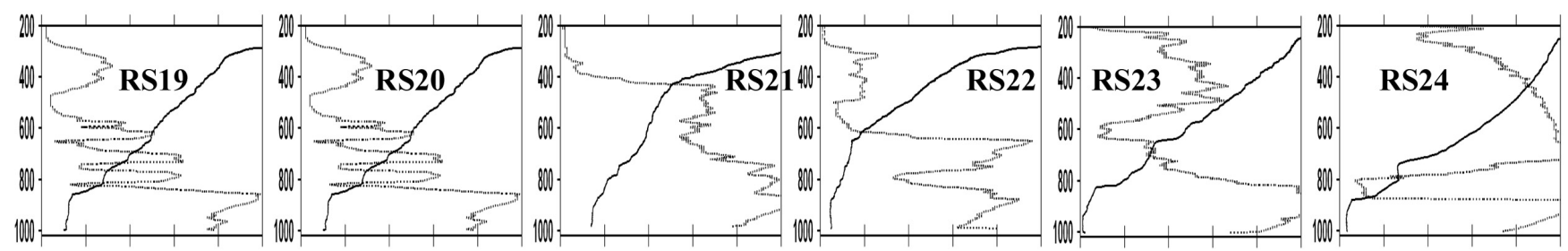

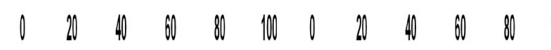

Fig. 3a. Vertical profile of potential temperature in ${ }^{\circ} \mathrm{C}$ (bold line - upper horizontal axis) and relative humidity in \% (dashed line - lower horizontal axis) for the 38 radiosondes. For locations, dates and times see Table 2. (a) for RS1 to RS24; (b) for RS25 to RS38.

wind profiles, respectively, derived from all the radiosonde releases.

A preliminary quality control was applied to all data on board and a rigorous quality control on the measures was then applied post-cruise to resolve a number of issues common to shipboard sampling of atmospheric and flux variables (instrument failures, superstructure influences, sampling gaps, and rain effects).

Wind data required significant scrutiny. Ideally, the sensors should be exposed to the air before it blows across the decks and superstructure. Location on a tall enough foremast is usually the best place. In order to have better accessibility for maintenance (which was an important issue with the Southern ocean sprays), the sensors were located above the wheelhouse. However, this location suffered from flow distortion from the foredeck, varying with relative wind direction. The Weatherpack anemometer was sited to the starboard side of the center line. Winds reported on the ship's system were irregularly collected from a Gill sonic anemometer located on the forward mast along the ship's centerline 

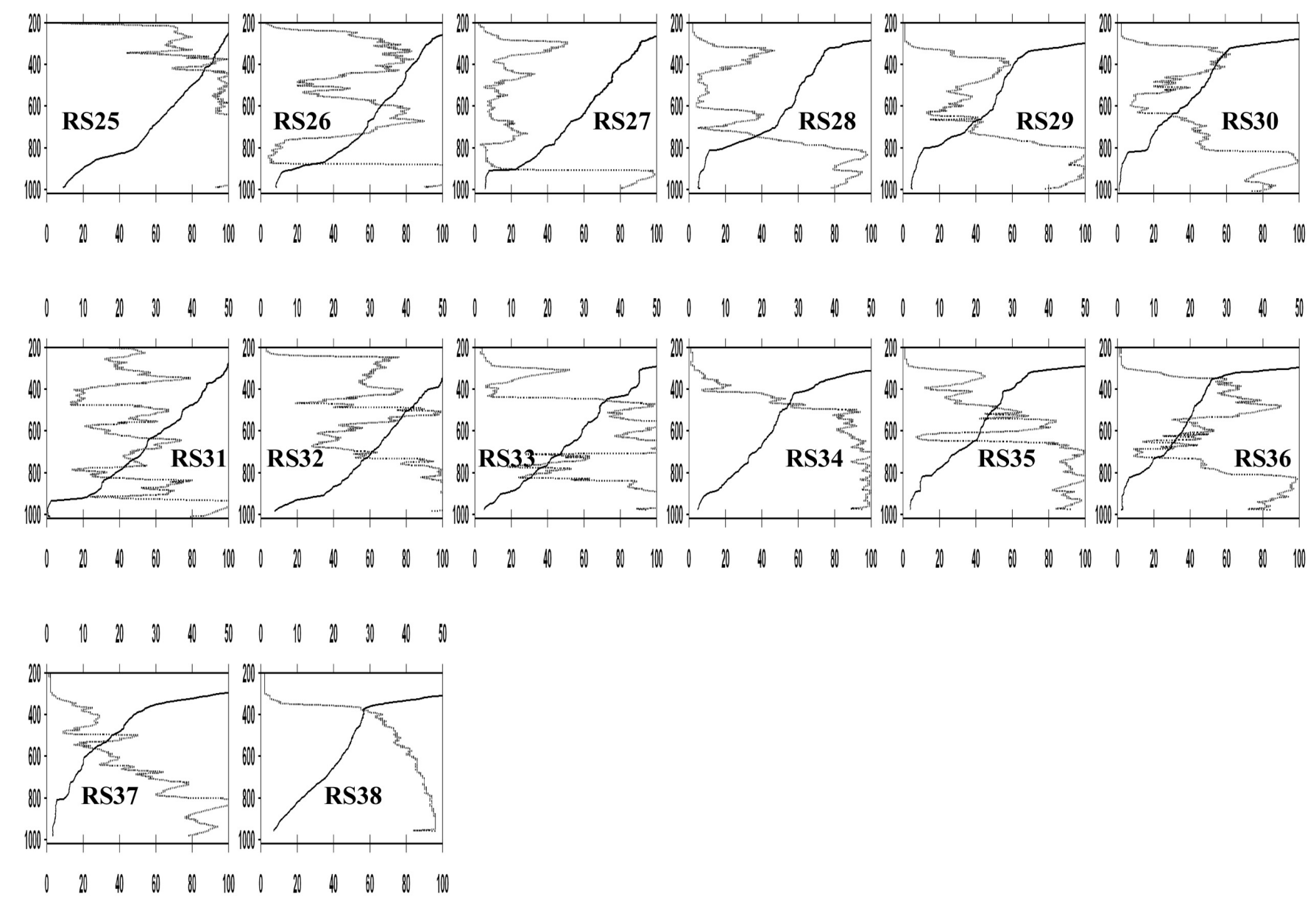

Fig. 3b. Continued.

but permitted some intercomparison with the Weatherpack anemometer. The measured speeds were accurate for most of the southward track when winds were taken on the bow. Other wind sensors on the ship, including an anemometer on top of the main mast, and another sonic anemometer on the cross-platform of the main mast, were not logged but were considered in real-time to check the wind distortion effect. Wind speed and direction are measured relatively to the ship displacement and must be combined with the ship's heading, course and speed to derive the true wind vector. However, the flow distortion by the ship changes the wind speed and direction by accelerating the wind around the obstacle of the ship. Consequently, errors in wind speed and direction measurement modify the true wind calculation and then the bulk fluxes. The correction to the wind distortion is seldom attempted but some single aerodynamic consideration and wind speed/direction distortion tables can be used to minimize the wind distortion errors. These tables indicate corrections to bring to the measurement as a function of wind intensity and incidence angle to the ship. All these approaches enabled the reduction of errors induced by wind distortion on the true wind measurement.

The Weatherpack air temperatures and M-AERI air temperature time series generally agreed in magnitude and timing, even if superstructural heating during low wind/high insolation periods introduced heat plumes into the Weatherpack air temperature data. Turbulent eddies and other flow distortions, such as wind acceleration over the edge of the passerelle and shadowing by the ship's mast also influenced air temperature and wind. These rapid fluctuations are obvious in both air temperature and wind time series for the several sampling units. Correlations were performed between data units to isolate lags and M-AERI air temperature data were used as reference to define heat plume events in the Weatherpack.

Bulk sea temperatures from the ship's thermosalinograph had also undergone an intercomparison with the Expendable Bathy Thermograph and CTD data collected at $6 \mathrm{~m}$ depth. Once the validity of the thermosalinograph temperature time 

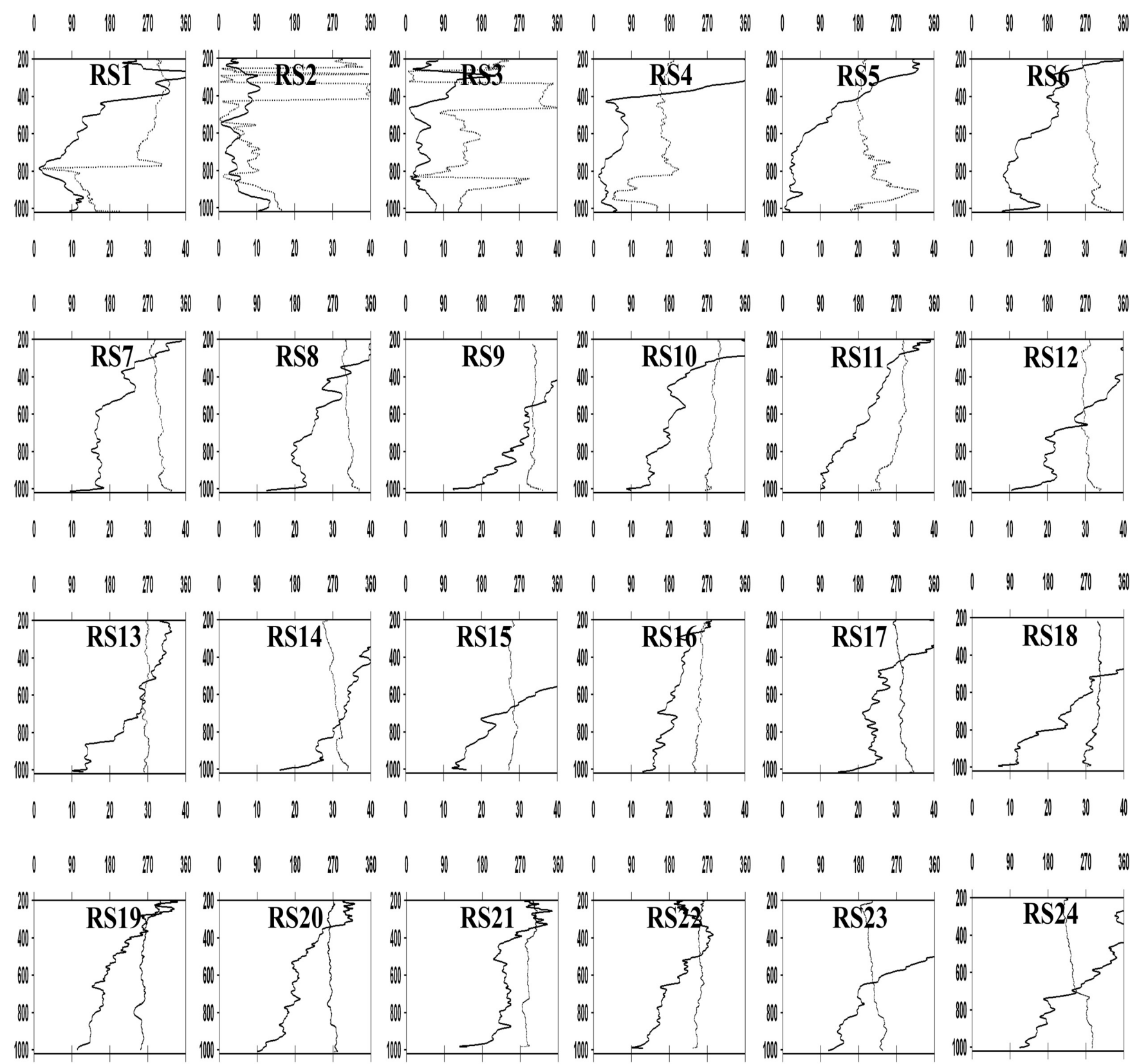

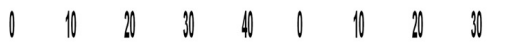

Fig. 4a. Vertical profile of wind speed in $\mathrm{m} \mathrm{s}^{-1}$ (bold line - lower horizontal axis) and wind direction in deg (dashed line - upper horizontal axis) for the 38 radiosondes. For locations, dates and times see Table 2. (a) for RS1 to RS24; (b) for RS25 to RS38.

series was ensured, skin-bulk temperature analyses were undertaken with the M-AERI data.

Radiation measured by the gimbaled Eppleys on the Weatherpack were checked to remove only main mast shadow events (and not cloud signatures) from the data. Comparison with the ship's plate-mounted pyranometer on the second forward mast provided another data control.

Eventually, the surface turbulent heat fluxes deduced from the in-situ observations were computed using COARE "bulk flux" algorithm (Fairall et al., 2003) (see Figs. 2, 6, 8). The turbulent heat flux (THF) is the sum of the sensible heat flux (SHF) and the latent heat flux (LHF). The in-situ solar radiation and net longwave radiation at the surface are also presented with the net heat flux at the surface. Additionally, the stability parameter $\zeta=z / L$ is also derived from the COARE algorithm (Fairall et al., 2003). It is used to highlight the stability of the lower atmospheric boundary layer. $L$ is the Obukhov length and $z$ is altitude (generally taken at 

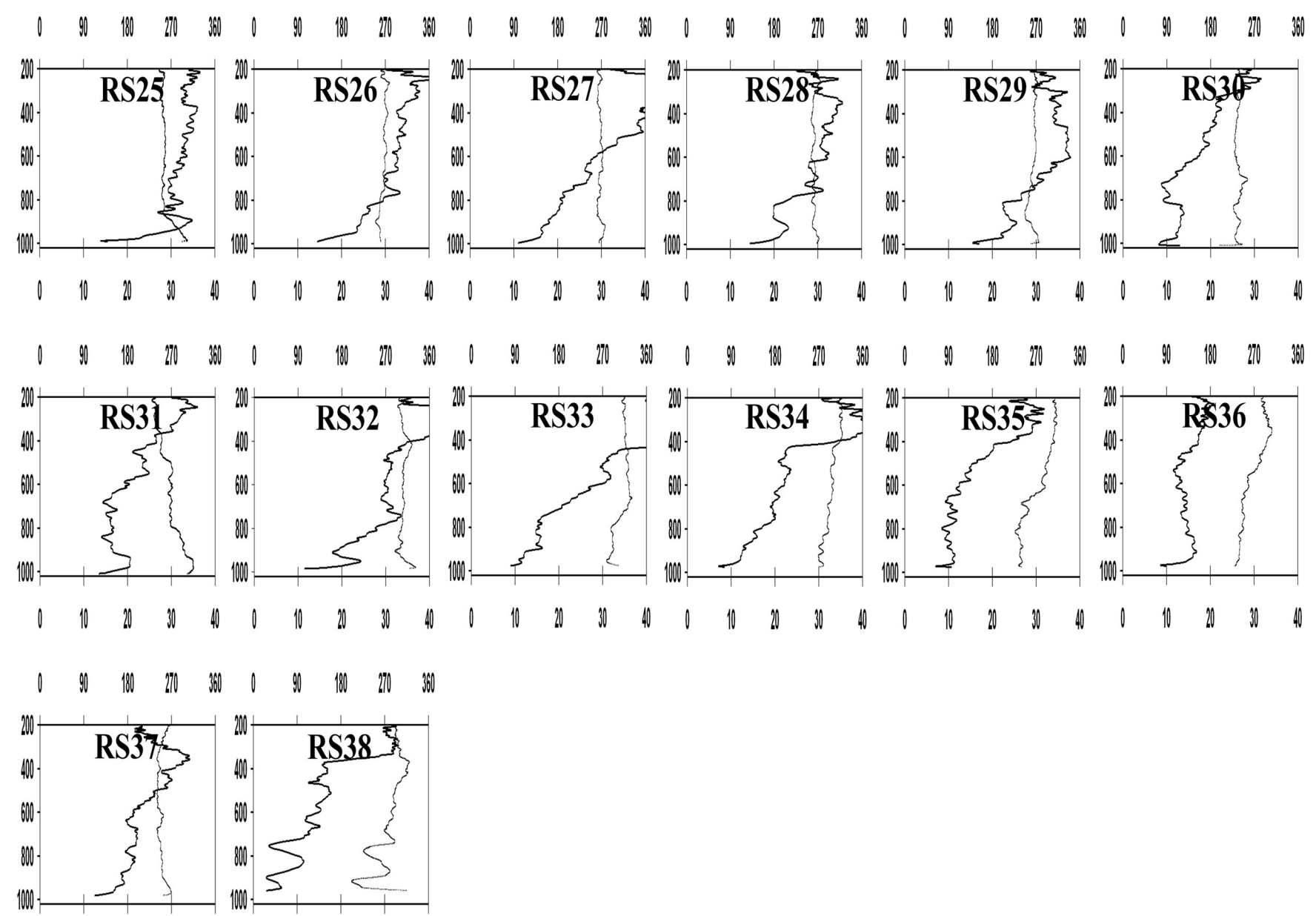

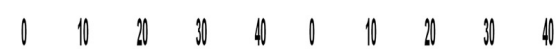

Fig. 4b. Continued.

$10 \mathrm{~m}$ height). Negative stability parameter implies statically unstable surface layer, positive implies statically stable surface layer. The $\zeta$ magnitude must not be considered. Note that the Obukhov length $(L)$ is a scaling parameter related to the turbulent kinetic energy of the lower atmospheric boundary layer. $L$ is proportional to the height above the surface at which buoyant factors dominate over mechanical (shear) production of turbulence (Stull, 1988).

Note that the cruise started on the 13 February but the atmospheric measurements started the 16 February.

\section{MABL stability over the SAF (anticyclonic eddy )}

From the 26 February (day 57) at 20:32 UTC to 28 February (day 59) at 10:00, the ship stayed at a fixed location $\left(42.47^{\circ} \mathrm{S} / 8^{\circ} 93^{\prime} \mathrm{E}\right)$. It was located south of the $\mathrm{S}$ eddy and north of the SAF and the M eddy (see Sect. 2). During that period, four radiosondes (from rs8 to rs11- see Table 2) were released. The synoptic situation is illustrated in Figs. 5a-d with the eastward displacement of a low pressure system. Its northern part was located over the ship the 27 February before noon. Significant in-situ wind speed increase as well as a direction change from northwesterly to southwesterly were thus observed before noon (Figs. $6 \mathrm{~b}$ and $5 \mathrm{~b}, \mathrm{c}$ ). The relative humidity and air temperature significantly decreased accordingly with the advection of the Antarctic cold and dry air (due to the southwesterly wind) while during the 26 February, the relative humidity and air temperature were relatively high due to the advection of the subtropical air mass associated with the northerly wind.

During this long station, the air temperature was initially higher than the SST until 14:00 UTC (Fig. 6a) the 27 February (day 58). Due to the advection of warm and humid air from the north, the turbulent heat fluxes remained weak and did not tend to destabilize the MABL. The rs8 profile (Fig. 7) thus exhibits a stable boundary layer (SBL) on early 27 February (00:00 UTC), also known as a classical nocturnal boundary layer (NBL). Note that these stable conditions persisted from the 26 February (profiles rs6 at 12:00 UTC and rs7 at 18:00 UTC - Fig. 3). The SBL is thus more a result 


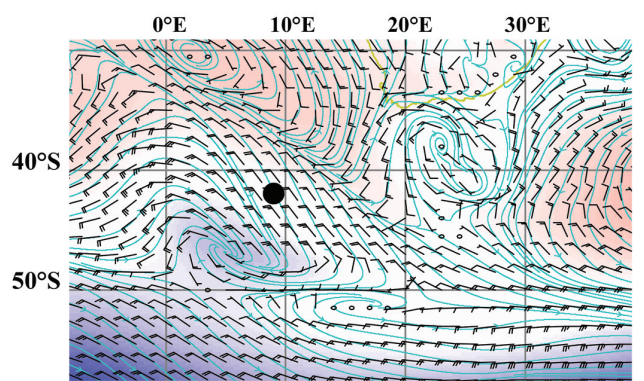

a) $27 / 02 / 2008-0000$ UTC

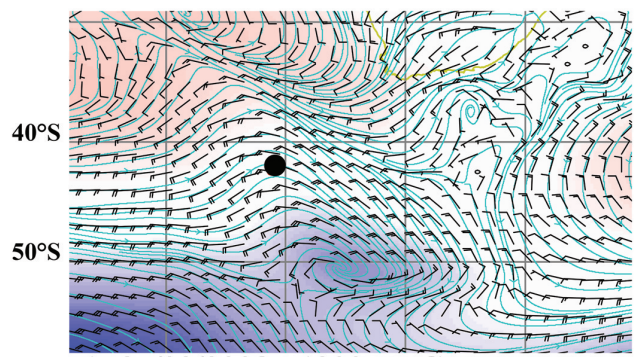

c) $27 / 02 / 2008$ - 1200 UTC

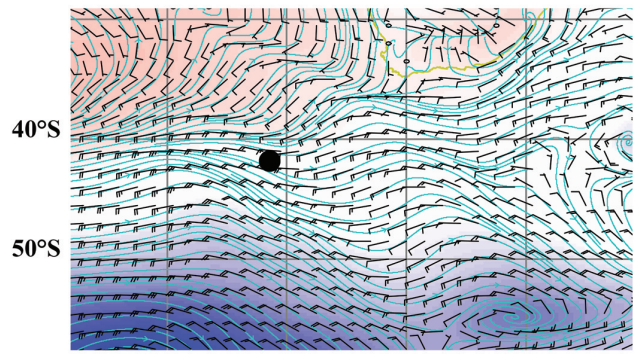

e) 28/02/2008 - 0600 UTC

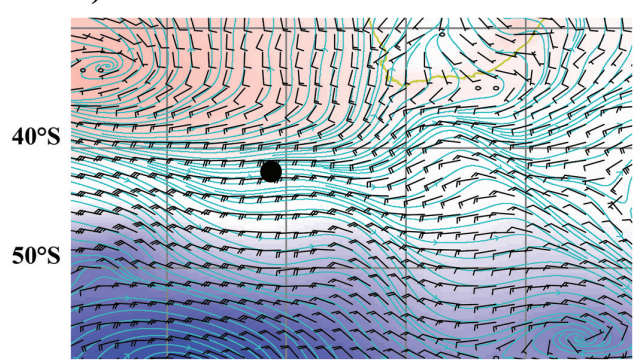

g) 28/02/2008 - 1800 UTC

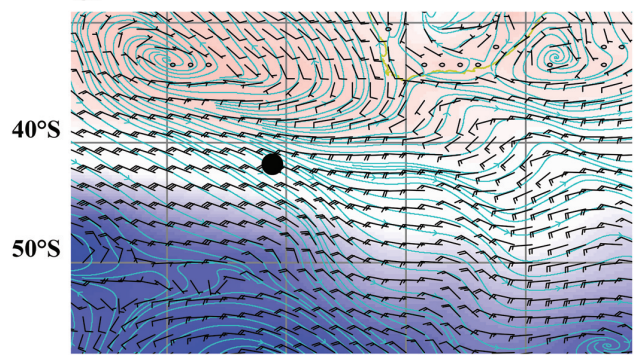

i) $29 / 02 / 2008$ - 0600 UTC

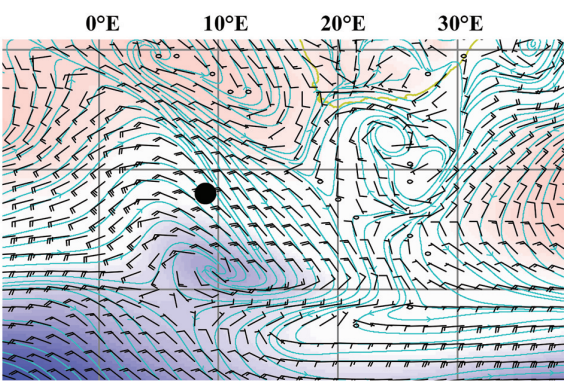

b) $27 / 02 / 2008-0600$ UTC

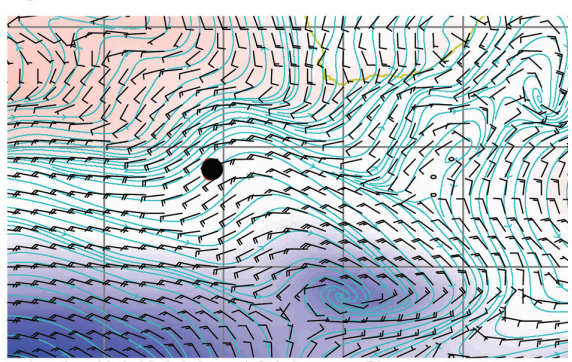

d) $27 / 02 / 2008$ - 1800 UTC

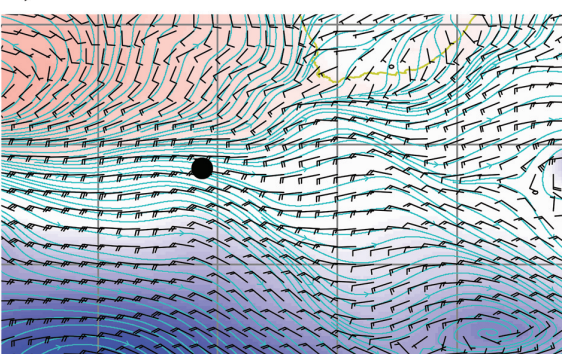

f) $28 / 02 / 2008$ - 1200 UTC

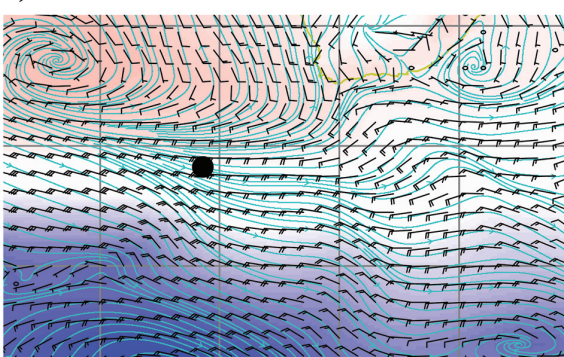

h) $29 / 02 / 2008$ - 0000 UTC

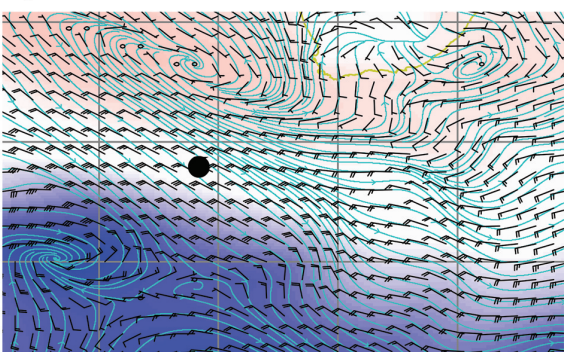

j) 29/02/2008 - 1200 UTC

972

1042 (hPa)

1007

Fig. 5. Synoptic situation from the 27 February to the 29 February 2008, before, during and after the ship crossed the SAF (from ECMWF ERA interim reanalysis). Colored background is the medium sea level pressure; light blue isolines are streamlines at $10 \mathrm{~m}$ height. Wind barbs (in knots) are overlaid. Black points indicate the ship location. Brown line is the South African coastline. 

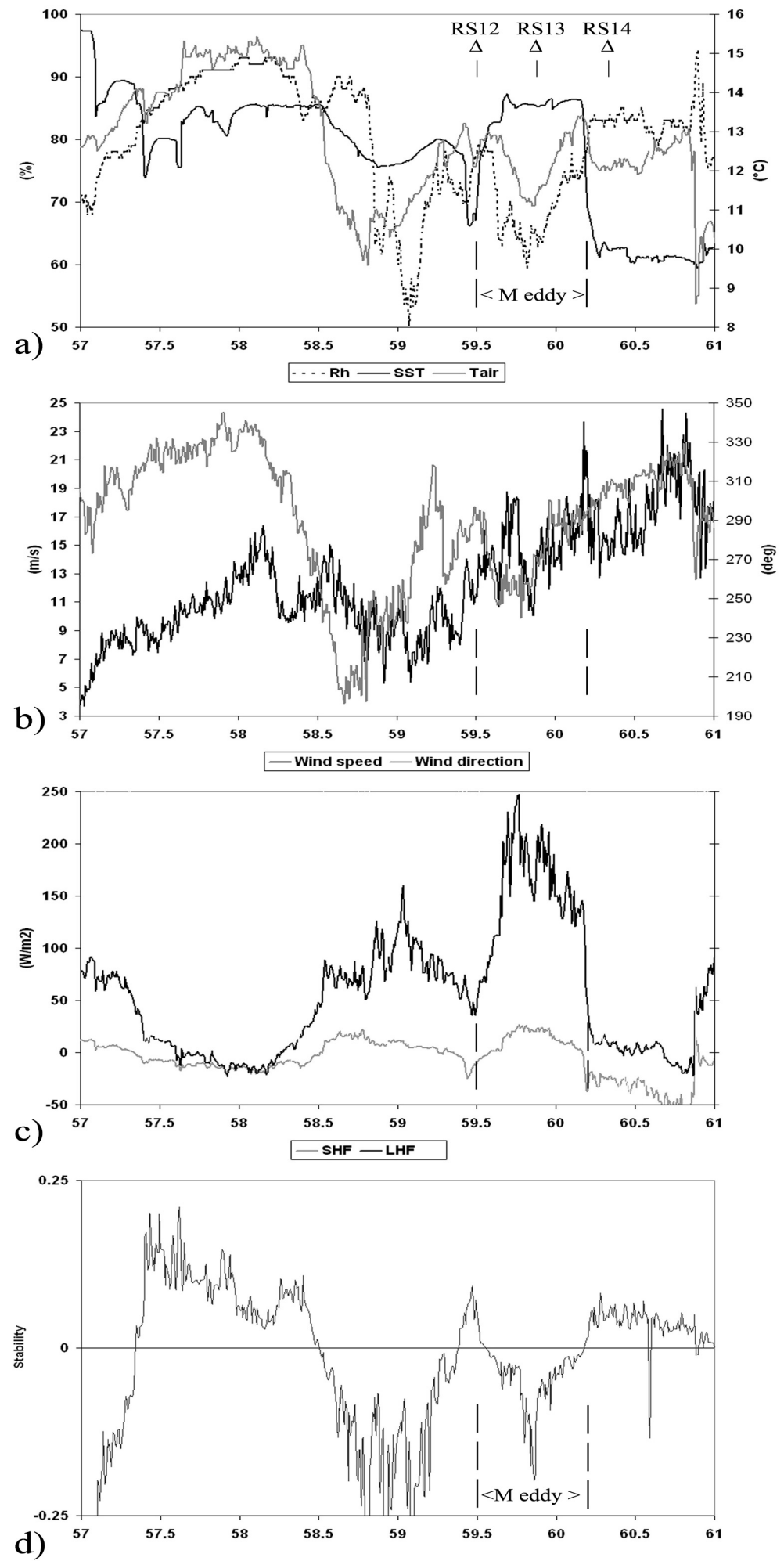

Fig. 6. Time series for (a) relative humidity (dashed black curve; left vertical axis), SST and air temperature (black and grey curves respectively; right vertical axis); (b) wind speed and direction (black and grey lines respectively), left vertical axis is wind speed and right vertical axe is direction; (c) sensible and latent heat fluxes (grey and black curves respectively); (d) stability parameter at ten meters height, $\zeta_{10}=10 / L, L$ is the Obukhov length; $\zeta$ positive for stable conditions, $\zeta$ negative for unstable conditions. For all the frames, the horizontal axis is the day number after the 1 January 2008. The vertical dashed black lines are the location of the oceanic fronts. The location of the RS12, RS13, RS14 releases is stated. 
of the synoptic situation rather than a classical NBL because of the northwesterly flow that enhanced the MABL stratification by advecting warmer air than the SST. The SBL persisted for the rs8 (00:00 UTC) sounding, however, a mixed layer then appeared aloft the stable layer for the rs9 sounding (06:00 UTC) according to the low pressure displacement towards the ship (see Fig. 5). This mixed layer (also known as residual layer - RL) is the result of a vertical mixing mainly enabled by the turbulent kinetic energy (TKE) associated with the vertical wind shear (see Fig. 7).

At 12:00 UTC (rs10) and 18:00 UTC (rs11) the 27 February, the SBL disappeared, then a mixed layer from the surface with a residual layer aloft appeared. That occurred accordingly with the wind direction shift and thus the advection of air mass from the southwest. As soon as the wind passed from a northerly meridional component to a southerly one, the air temperature decreased (as well as humidity) and the air sea gradient (Fig. 6a) was then inverted after noon, triggering an increase of the THF (Fig. 6b, c) and thus favouring the turbulent mixing of the lower part of the MABL; the stability parameter Fig. 6d also moved from positive (stable) to negative (unstable).

Finally, the MABL was stabilized by the northwesterly warm and wet air advection before the low pressure system arrival and then, the MABL was destabilized (from 12:00 UTC, 27 February, see also $\zeta$ sign in Fig. 6d) by the dynamics and the change in the air advection. The synoptic system triggered a dynamic mixing at the MABL top while the cool surface air advection enhanced the heat release at the base of the MABL, inducing a thermal vertical mixing. As a result, a deepening of the mixed layer (up to $900 \mathrm{hPa}$ ) was observed.

The SAF was actually crossed between the 28 (day 59) and 29 (day 60) February. The SST time series (Fig. 2) did not exhibit an abrupt decrease as expected for this front because of the presence of the two warm oceanic eddies encountered at this location (see Sect. 2 and Arhan et al., 2011). The S eddy (located from $40.6^{\circ} \mathrm{S}$ to $42.5^{\circ} \mathrm{S}$ ) presented a weak surface SST signature, except over its southern part, where the SST increased of $1{ }^{\circ} \mathrm{C}$ between the early 28 February and the mid morning (Fig. 6a). The SST time series then presented a minimum at $10.7^{\circ} \mathrm{C}$ and raised up by $3{ }^{\circ} \mathrm{C}$ directly afterwards, corresponding to the northern part of the $\mathrm{M}$ eddy (located from $42.7^{\circ} \mathrm{S}$ to $44^{\circ} \mathrm{S}$ ) which had a clear SST surface signature. The SST within the M eddy core reached nearly $14^{\circ} \mathrm{C}$ before the abrupt decrease of $4^{\circ} \mathrm{C}$ ( 29 February morning) when the ship sailed out from the eddy. The air temperature decreased between the two eddies from the 27 February and then increased the 28 February. It must be noted that there is an abrupt air temperature decrease while the SST stayed nearly at $14^{\circ} \mathrm{C}$. After noon, the 28 February (day 59), the observed wind direction changed from $290^{\circ}$ to $250^{\circ}$ (Fig. 6b). Consequently, cold air was advected from the southwest, explaining the air temperature decrease. Note that this wind direction variation does not appear in the ECMWF ERA re- analysis product (Fig. 5f, g) since the wind direction change occurred between two reanalysis cycles (between 12:00 UTC and 18:00 UTC). It must be also noted that once this southwesterly wind event was ended, the air temperature increased anew when the ship reached the southern M eddy border and then decreased again as the extreme southern part of the SAF.

No synoptic information can explain this wind direction change. O'Neill et al. (2010) suggested that the wind direction is sensitive to an SST front as well as the wind speed. The $140 \mathrm{~km}$ diameter and location of the M eddy let consider it as a part of the SAF (see Arhan et al., 2011). O'Neill et al. (2010) suggested that the surface winds turn anticyclonically when surface wind flows from cool to warm SST. This anticyclonic wind direction rotation was actually observed and its maximum was located at the eddy centre. This wind direction rotation turned back afterwards and was then less marked until the southern eddy border, to reach again the same wind direction observed outside the eddy.

Figure 6a also illustrates that the SST anomaly of the two eddies had influence on the turbulent heat fluxes (as well as on the net heat fluxes - Fig. 2c) at the ocean surface. Note that the $\mathrm{S}$ eddy exhibited a slight increase of the turbulent heat flux while the M eddy released more than twice the turbulent heat flux released by the $S$ eddy. Figure 6a reveals the well-defined SST anomaly between the 28 February (day 59) and the 29 February (day 60), exactly above the location of eddy M (see Arhan et al., 2011). At this location the air-sea temperature gradient was inverted compared to outside the eddy, and induced a positive SHF of $15 \mathrm{~W} \mathrm{~m}^{-2}$ on average (reaching up to $25 \mathrm{~W} \mathrm{~m}^{-2}$ ) from the ocean to the atmosphere. In the same latitude interval, the LHF also presents a high average value of $180 \mathrm{~W} \mathrm{~m}^{-2}$ (reaching up to $247 \mathrm{~W} \mathrm{~m}^{-2}$ ), strongly contrasting with those outside the eddy. The net heat fluxes released to the atmosphere by the M eddy thus reached up to $300 \mathrm{~W} \mathrm{~m}^{-2}$. The negative stability parameter over the $\mathrm{M}$ eddy (Fig. 6d) indicates the instability of the lower atmosphere generated by the air-sea temperature gradient and illustrated by the peak of turbulent heat fluxes towards the atmosphere over the M eddy.

As eddies were crossed during nighttime, the incoming solar radiations were insignificant and the net heat flux at the ocean surface was mainly due to the surface turbulent heat fluxes (SHF and LHF). Consequently, over this region, it is evident that the mesoscale oceanic turbulences (here as a form of eddies) significantly increased the release of heat in the atmosphere mainly via the LHF.

Three atmospheric soundings were performed above the SAF, from 28 to 29 February (rs12, rs 13, rs14) hence above the $\mathrm{M}$ eddy. The first one was released at the northern border of the eddy, the second in the middle of the core, while the third one was released beyond the southern side of the eddy (where the SAF was actually overtaken). The rs 12 sounding performed the 28 February at 12:00 UTC exhibits a poorly mixed but stable layer (Fig. 7). Figure 6 shows that the air temperature was $12.1^{\circ} \mathrm{C}$ and SST was $10.7^{\circ} \mathrm{C}$ at $12: 00$ UTC. 

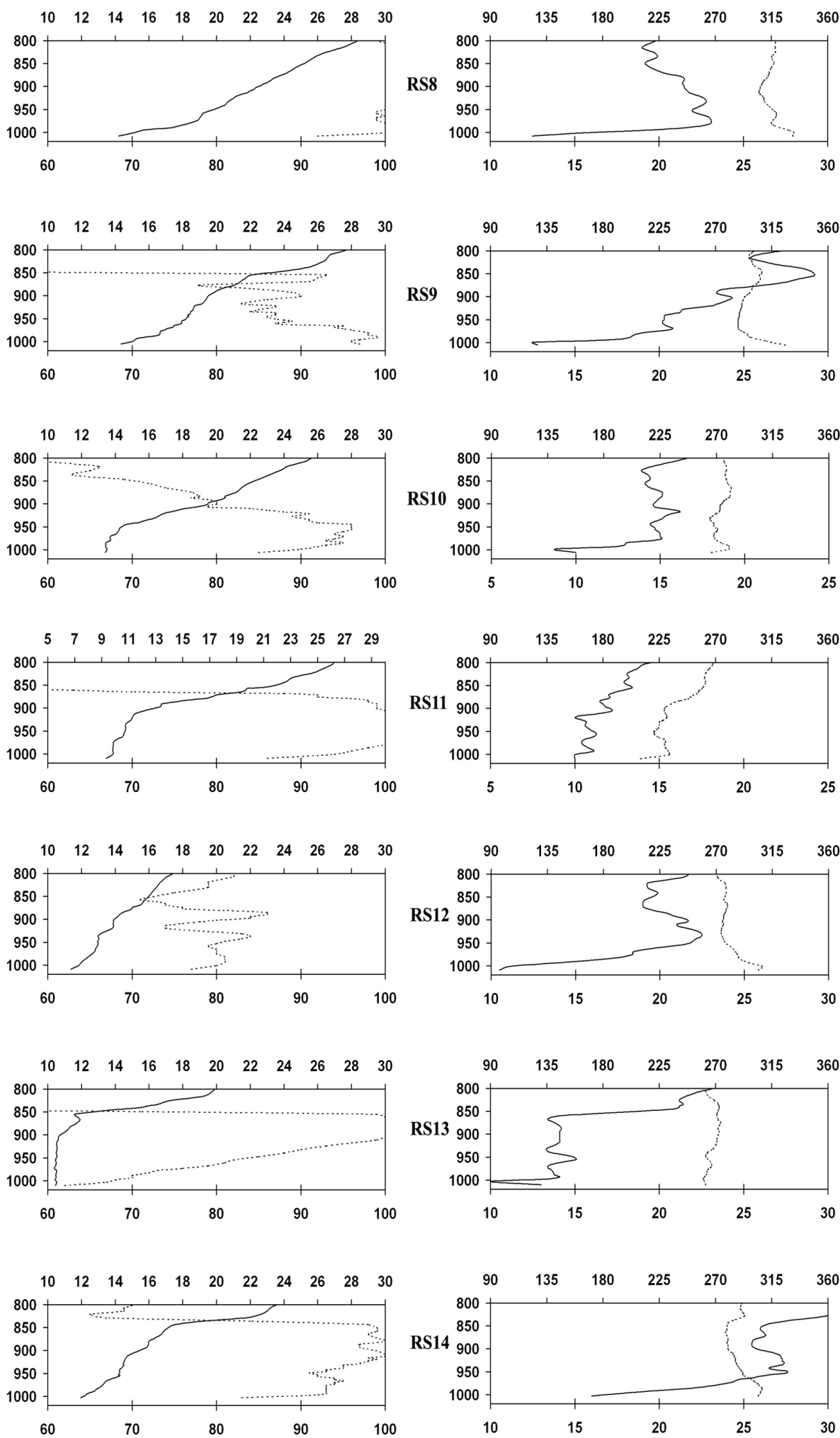

Fig. 7. Left column: Vertical profile of potential temperature in ${ }^{\circ} \mathrm{C}$ (bold line - upper horizontal axis) and relative humidity in $\%$ (dashed line - lower horizontal axis) for the rs8 to rs 14 radiosondes. Right column: Vertical profile of wind speed in $\mathrm{m} \mathrm{s}^{-1}$ (bold line - lower horizontal axis) and wind direction in deg (dashed line - upper horizontal axis) for the rs8 to rs14 radiosondes. For locations, dates and times see Table 2. 
Such an air-sea temperature gradient tends to cut off the vertical heat flux from ocean to atmosphere (the turbulent heat flux was low: $23.4 \mathrm{~W} \mathrm{~m}^{-2}$ ) and to stabilize the low atmosphere (see also the positive stability parameter at the rs 12 location, Fig. 6d).

The rs13 radiosonde was released above the $\mathrm{M}$ eddy core at 19:55 UTC, separated by $70 \mathrm{~km}$ to the $\mathrm{rs} 12$ radiosonde. There is evidence of a mixed atmospheric boundary layer (up to $900 \mathrm{hPa}$ ) with a cloud layer aloft (where Rh reached $100 \%$ ) between $850 \mathrm{hPa}$ and $900 \mathrm{hPa}$. The observed instability (see also instability parameter value Fig. 6d) from the surface was associated with the higher SST in the eddy core. Compared to rs 12 , the air-sea temperature gradient was inverted (air temperature: $12^{\circ} \mathrm{C}$, SST: $13.62^{\circ} \mathrm{C}$ - twice as the gradient observed outside the eddy). That induced a peak in the turbulent heat flux $\left(274 \mathrm{~W} \mathrm{~m}^{-2}\right)$ (Fig. 6c) which released an important amount of heat at the base of the atmospheric boundary layer, inducing the vertical instability. This process is stopped by an inversion layer where condensation occurred, with the presence of clouds.

The rs14 atmospheric sounding was performed when the ship crossed the southern border of the M eddy as well as beyond the SAF. The vertical profile (Fig. 7) exhibits a stable boundary layer (as for rs 12) from surface to $950 \mathrm{hPa}$ with a nearly neutral layer aloft up to $900 \mathrm{hPa}$. From $850 \mathrm{hPa}$ to $900 \mathrm{hPa}$ a residual layer appears. At this time, the meridional wind component was again mainly northerly, then the warm and moist air arrived over the colder sea surface induced a stabilization of the lower MABL (the stability parameter actually passed from negative to positive).

\section{Synoptic control of the MABL variability over the STF front}

The STF appeared as a strong SST gradient of $-4{ }^{\circ} \mathrm{C}$ per $100 \mathrm{~km}$ observed around midday the 23 February (day 54) (Fig. 8a). The ship crossed the STF between the 23 (day 54) and 24 February (day 55) and the wind speed increased accordingly $\left(+6 \mathrm{~m} \mathrm{~s}^{-1} ;\right.$ Fig. 8 b). Figures $8 \mathrm{a}$, b suggest that the oceanic fronts seem associated with the changes in the low atmospheric dynamics by influencing winds, however, these changes in the wind magnitude can be explained by coincident synoptic weather variability. Figure 9 presents the synoptic situation in the ECMWF ERA interim reanalysis. A low pressure system located to the northeast of the ship and centred on the Cape Basin deepened during these days and induced a wind speed increase. This latter was strengthened by the eastward displacement of a high pressure system, which was located to the south along $43^{\circ} \mathrm{S}$. For these reasons, the wind increased uniformly over a larger area than the STF area only (Fig. 9b). Note that the wind stayed mainly southeasterly and advected cold and dry air mass over the front (see $R_{\mathrm{h}}$ on Fig. 8a). Consequently, a "strong breeze" wind blew from a cold SST to a warm SST. The MABL response
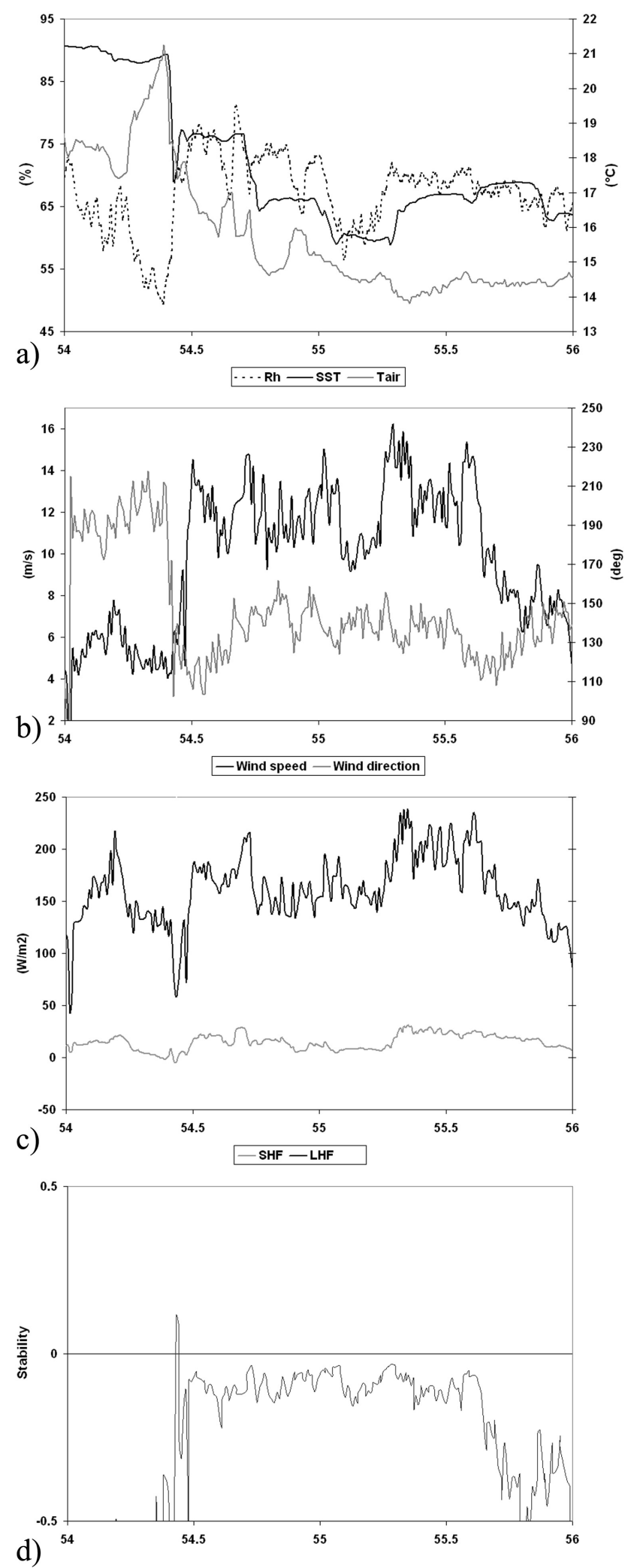

Fig. 8. Same as Fig. 6 but for days 54 to 56 . 

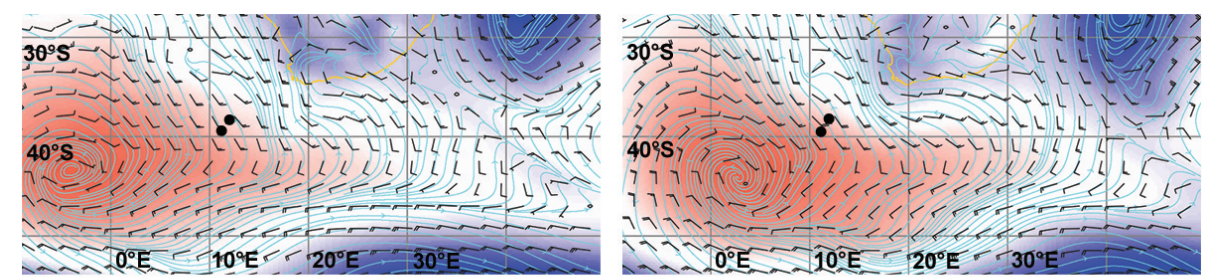

a) $23 / 02 / 2008-1200$ UTC

b) $24 / 02 / 2008$ - 0000 UTC
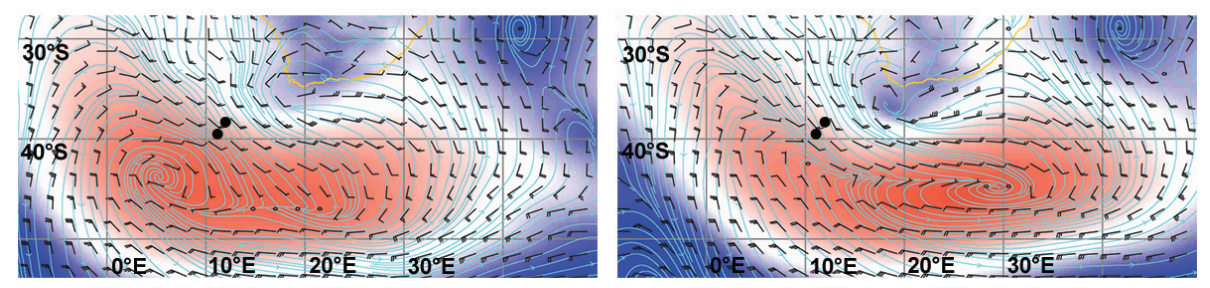

c) $24 / 02 / 2008-1200$ UTC

d) $25 / 02 / 2008-0000$ UTC

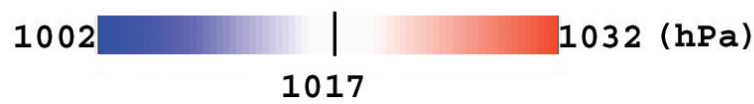

Fig. 9. Synoptic situation when the ship crossed the STF (from ECMWF ERA interim reanalysis). Colored background is the medium sea level pressure, light blue isolines are streamlines at $10 \mathrm{~m}$ height. Wind barbs (in knots) are overlaid. Black points indicate the rs1 and rs2 release locations. Brown line is the South African coastline.
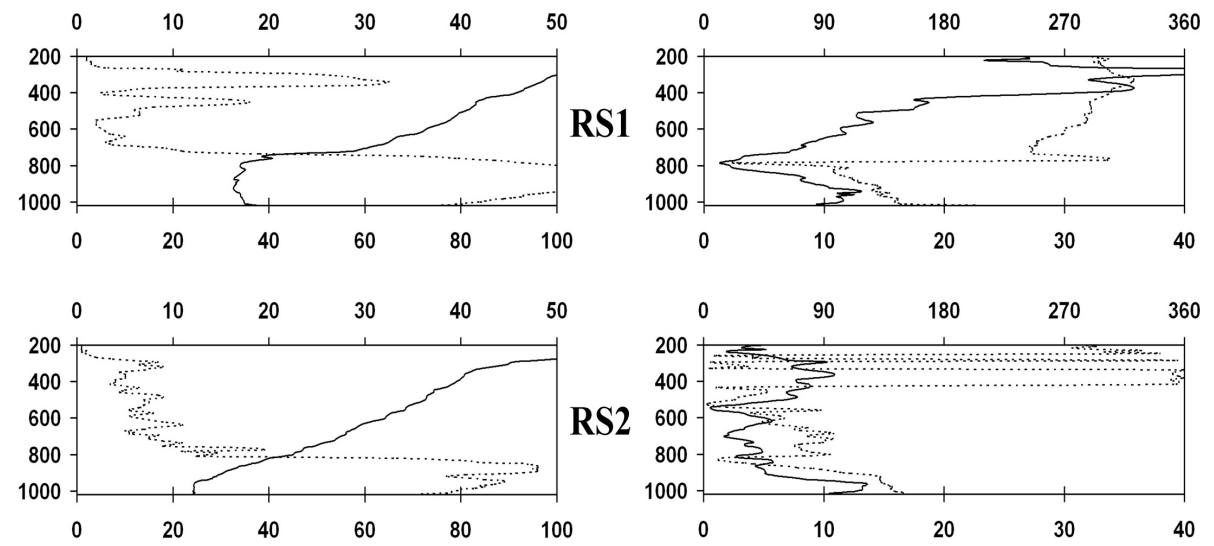

Fig. 10. Same as Fig. 7 but for the rs 1 and rs2 radiosoundings.

to an ocean front with a strong wind aloft has been already described by Song et al. (2006) and Spall (2007). The increase of turbulent heat fluxes downwind combined to the wind shear tended to destabilize and mix the BL. A deepening of the BL is thus expected downwind of the front (over the warmer SST) due to a change in the momentum balance between upwind and downwind to the front. Two atmospheric radiosondes were released in the vicinity of the STF the 23 and 24 February (rs1 and rs 2 respectively). The rs1 was released when the ship was within the STF, while the rs2 was released at the south of the STF. At the rs1 and rs2 locations, the low MABL was unstable (see Fig. 8d, stability parameter, and Fig. 10). However, the rs2 boundary layer was not as deep as the rs1 and the latter revealed a shallow unstable internal mixed layer bounded by a cloud layer at $900 \mathrm{hPa}$ with a residual layer aloft, whereas the rs2 profile did not exhibit saturation within the BL. The low-level cloud layer observed for the rs1 profile could be associated with the increase of latent heat flux release (Fig. 8c) induced by the cold and dry air advection over warm water. These differences in the MABL height and structure upwind and downwind of the STF are in agreement with previous observations over intensive frontal regions as described by Spall (2007) when a cold flow (here northwards) crosses an SST front from cold (here located south of the front) side to warm side (here located north of the front). The BGH observation illustrates the expected changes in the MABL profile observed north and south of the STF as previously observed for other oceanic region (Gulf Stream, Kuroshio). That complements previous observations conducted within the Agulhas region, relative 
to the moisture uptake (Lee-Thorp et al., 1999) and to the MABL change (Jury and Walker, 1988; De Mey et al., 1990; Jury, 1994) observed leeward the Agulhas retroflexion, while the BGH cruise STF observations were conducted windward the Agulhas retroflexion.

Note that the rs1 profile was likely not totally mixed at 16:21 UTC because the SST exceeded the air temperature by $2{ }^{\circ} \mathrm{C}$. That induced an upward heat flux (Fig. 8a, c) which destabilized the shallow boundary layer. This is sustained by the air flowing from cold to warm water. Figure $8 \mathrm{a}, \mathrm{b}$ indeed shows a surface wind of more than $12 \mathrm{~m} \mathrm{~s}^{-1}$ /from roughly $140^{\circ}$ which advected cold and dry air from the south. The humidity component straightened the upward heat flux since the incoming wind was dry and reached a warm SST region with a high potential evaporation. The evaporation was then enhanced corresponding to an observed LHF increase. Note that the rs 2 profile has been recorded in a similar synoptic condition (Fig. 9c).

\section{Diurnal cycle}

Figure 2c exhibits a diurnal cycle of the net heat flux at the surface driven by the solar radiation cycle. The turbulent heat fluxes do not follow this cycle and are more related to the air-sea temperature gradient and the relative humidity. The air-sea temperature gradient itself depends on the ocean dynamics (producing SST anomalies or not) and on the atmospheric synoptic situation which also drives the humidity advection that influence the potential evaporation (see Sect. 5). The signature of a diurnal cycle within the MABL is thus questionable. Over the SO region, the role of the diurnal cycle in the vertical MABL mixing is not well-documented, particularly when turbulent heat fluxes (influencing the thermal mixing from the base of the MABL) can vary considerably with synoptic wind variability, which could itself produce mixing because of the vertical shear. When considering the net heat flux balance (Fig. 5), one can note that the heat loss from ocean to atmosphere occurred mainly during the night (through turbulent processes), while the gain of heat for the ocean occurred during the day when incoming solar radiation is maximal, even if the shortwave radiation decreased as the ship moved southwards towards the pole. That suggests a diurnal cycle of the mixing of the low MABL since the turbulent heat fluxes participate in this mixing. However, even if this diurnal cycle is suspected in the vertical mixing, the modulation by the synoptic wind does not let a support for a dominant role of this diurnal cycle in the vertical mixing.

For instance, two atmospheric diurnal cycles were sampled with some radiosonde releases when long CTD station occurred during the cruise. The first diurnal cycle sampling was performed from the 26 February to 27 February (previously evocated in the Sect. 4). This sampling, performed north of the SAF and south of the STF, did not bring evi- dence of a diurnal cycle effect in the vertical mixing. The latter was actually dominated by the synoptic advection variability during this day.

The second diurnal cycle sampling was performed the 1011 March (day 70 at 12:00 UTC to day 71 at 06:00 UTC), with the release of four radiosondes (rs23 to rs26; see Table 2) between the PF and the SACCF. Figure 11 illustrates a succession of two synoptic low pressure systems located south of the ship with an eastwards displacement. The southwesterly winds measured during the first cycle persisted until 10 March 12:00 UTC (Fig. 11a, b, c). During the late 10 March afternoon, the second low pressure system (centred closer to the ship compared to the first one) produced westerly wind at 18:00 UTC then northwesterly until 11 March, 00:00 UTC, as well as a wind speed increase (Fig. 11d, e, f).

The rs23 sounding (day 70 at 12:00 UTC) presented an unstable low MABL with a mixed layer aloft (Fig. 12). This mixed layer was composed by a subcloud layer and a cloud layer aloft (up to $875 \mathrm{hPa}$ ). The rs24 (day 78 at 18:00 UTC) presented a similar profile excepting a decrease of the total BL height. The wind measured at the surface by the radiosondes rs24 (day 70 at 18:00 UTC) and the rs25 (day 71 at 00:00 UTC) did not exceed $15 \mathrm{~m} \mathrm{~s}^{-1}$, however, for the rs 25 , a strong wind was measured in the lower part of the boundary layer $\left(>25 \mathrm{~m} \mathrm{~s}^{-1}\right)$. This was related to the northern part of the strong gale passing over the ship before 22:30 UTC (Figs. 11 and 12).

The rs 25 profile (day $71-00: 00$ UTC) exhibited a very shallow subcloud stable profile (NBL) with a deep cloud layer aloft (illustrated by the humidity saturation up to $650 \mathrm{hPa}$ height). This is the result of the moist and warm northwesterly flux (Figs. 11, 12).

The rs 26 sonde (day 71 at 06:00 UTC) was released when the low pressure system was centred to the southeast of the ship (Fig. 11f) with westerly wind. A shallow subcloud stable layer with a well-mixed cloud layer aloft (shallower than the one observed in the rs25) composed the BL. The MABL then presented an NBL and an unstable BL during afternoon, which is the classical component of a BL diurnal cycle mixing. However, this characteristic is the result of the occurrence of two synoptic systems rather than to a MABL diurnal variability associated with the radiation cycles.

\section{Discussion}

Numerous synoptic systems crossed the ship track each time the oceanic fronts were sampled. Consequently, at event or daily scale, it has been difficult to exhibit a direct front effect on the low level wind dynamics as suggested mainly over midlatitudes, subtropical and tropical regions or within the Agulhas current system by Xie et al. (1998), Chelton et al. (2001, 2004), O'Neill et al. (2003, 2005), Tokinaga et al. (2005), Song et al. (2006) or Chelton and Xie (2010). Note that in these previous studies, the timescale considered 

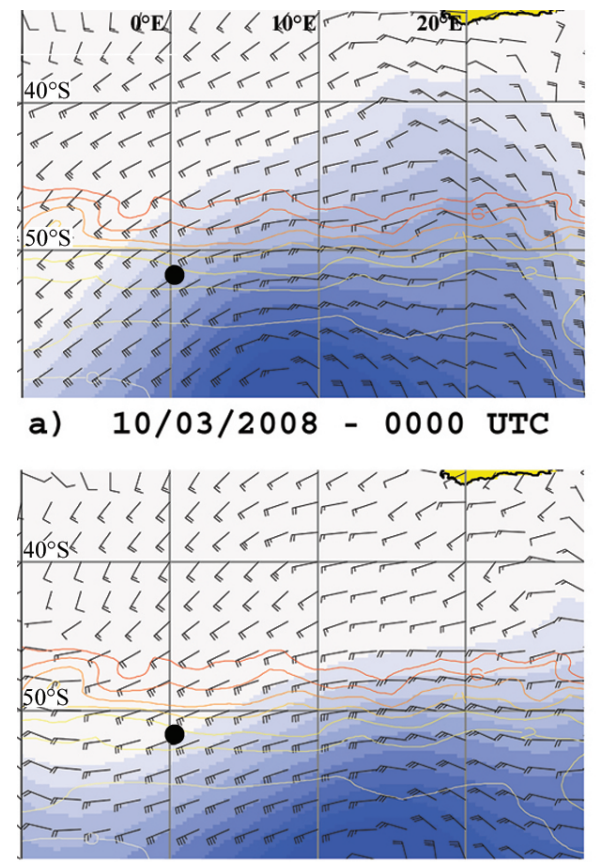

c) $10 / 03 / 2008-1200$ UTC

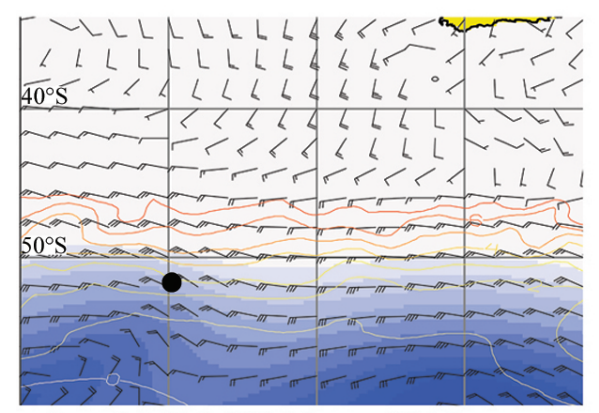

e) $11 / 03 / 2008-0000$ UTC
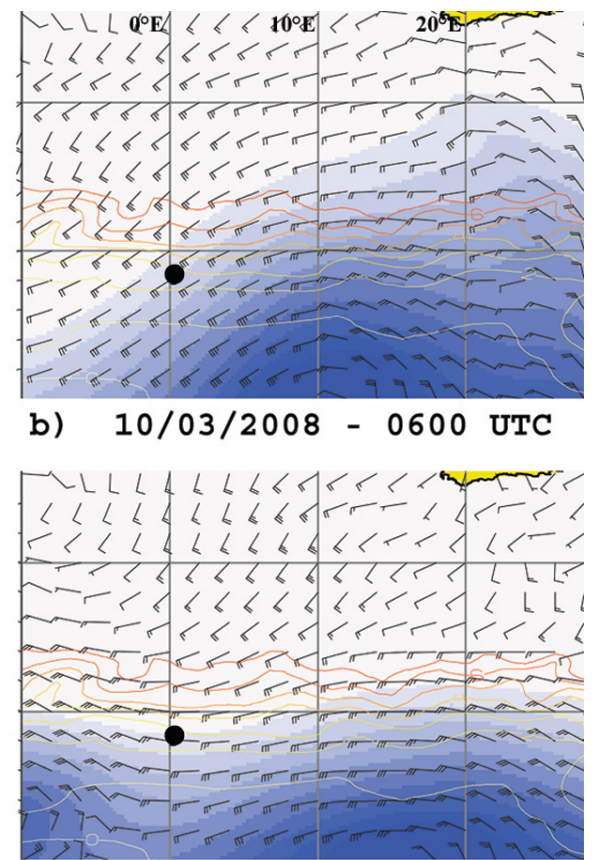

d) $10 / 03 / 2008-1800$ UTC

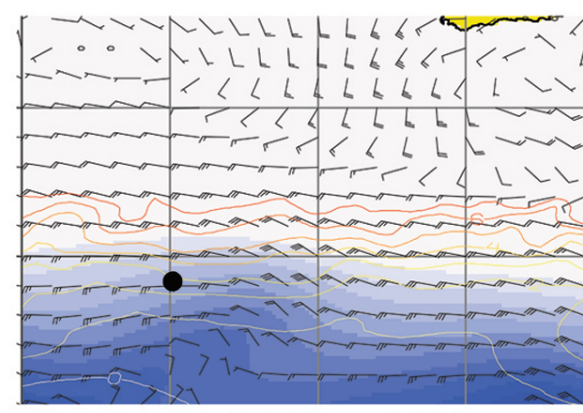

f) $11 / 03 / 2008-0600$ UTC

992
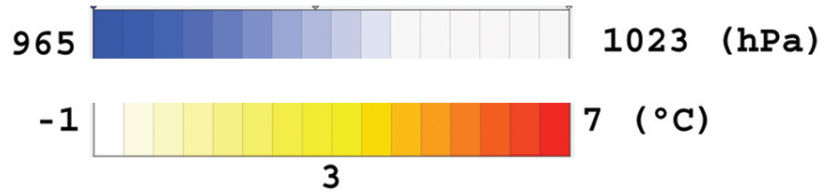

Fig. 11. Synoptic situation during the 10 and 11 March (from ECMWF ERA interim reanalysis). Colored background is the medium sea level pressure, isolines are SST (contour interval is $1^{\circ} \mathrm{C}$ ). Wind barbs (in knots) are overlaid. Black points indicate the ship location $\left(42.5^{\circ} \mathrm{S} / 9^{\circ} \mathrm{E}\right.$ ).

for the air-sea interaction was mainly longer than a week or more, precisely to remove high frequency variability. However, on can consider that the M eddy is a part of the SAF front since it is a location where mesoscale eddy are generated from a meandering of the front. Consequently, one can say that the M eddy and the SAF front exhibited a direct effect on the MABL. A similar Agulhas eddy (centred at $\sim 42^{\circ} \mathrm{S}-20^{\circ} \mathrm{E}$ ) was sampled in June-July 1993 (Rouault and Lutjeharms, 2000). This latter released $500 \mathrm{~W} \mathrm{~m}^{-2}$ of latent heat fluxes and $350 \mathrm{~W} \mathrm{~m}^{-2}$ of sensible heat flux compared to the $250 \mathrm{~W} \mathrm{~m}^{-2}$ of the $\mathrm{M}$ eddy turbulent heat fluxes. The
1993 eddy had somewhat the same origins as eddy M, but was likely younger, which explains the huge difference in terms of heat flux measured for these two eddies. It had a surface temperature up to $\sim 17^{\circ} \mathrm{C}$ and a $250 \mathrm{~m}$-thick mixed layer, whereas eddy $\mathrm{M}$ had surface temperatures slightly below $14{ }^{\circ} \mathrm{C}$, and a $\sim 50 \mathrm{~m}$ summer mixed layer. The direct and derived atmospheric measurements above the $\mathrm{M}$ eddy presented in this paper enabled the description of some thermodynamic effects of the $M$ eddy on the vertical atmosphere aloft (see Sect. 4). The warm SST anomaly of the eddy core induced a vertical destabilization of the atmosphere by 

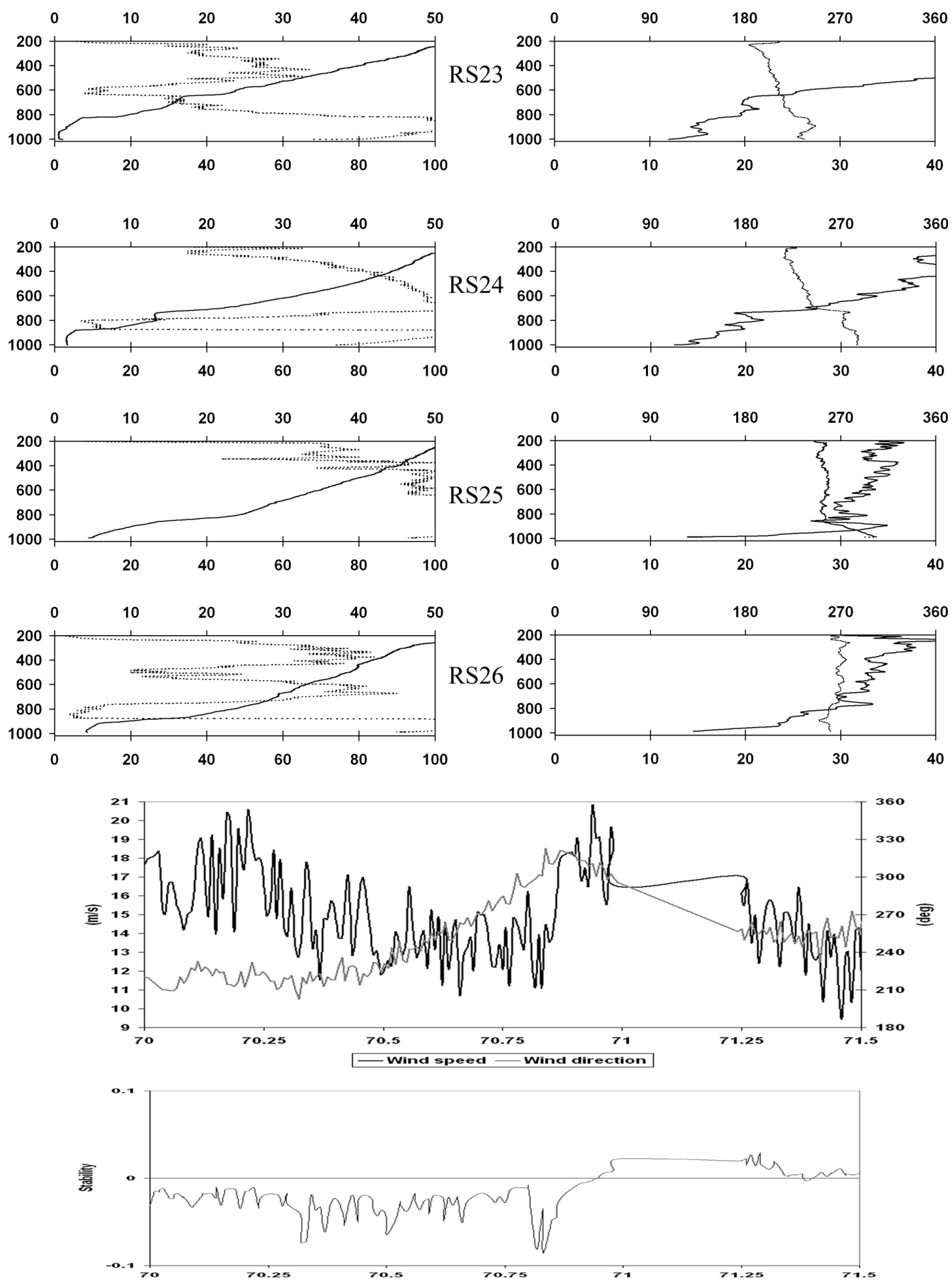

Fig. 12. Same as Fig. 7 but for the rs 23 to rs 26 radiosoundings. The two additional frames present the wind speed and direction as well as the stability parameter as stated in Fig. 6.

increasing the vertical turbulent heat transfer from the ocean to the atmosphere (when the air temperature is lower than the SST). This transfer is mainly driven by the latent heat flux rather than the sensible heat flux. This latter is roughly five times less efficient than the former (see Fig. 16 in Arhan et al., 2011) because of the lower relative humidity above the eddy centre (Fig. 6a) due mainly to the southwesterly wind rotation during the measurement.

The modulation of the turbulent heat fluxes by the synoptic systems has been underlined in Sects. 4, 5, 6 with the 
in-situ data recorded. The wind direction changes induced some changes in the characteristic of the air masses advected in terms of temperature and humidity, which directly control the surface heat flux variability that participate to the mixing of the low MABL. Figure $2 b$ illustrates that, north of the STF, the mean wind intensity was low $\left(6.3 \mathrm{~m} \mathrm{~s}^{-1}\right)$ and direction was variable until the 26 February (day 57). From this date, and south of the STF until the end of the leg at $57.3^{\circ} \mathrm{S}$, the ship sailed in the roaring forties and beyond. The mean wind intensity then became $13.3 \mathrm{~m} \mathrm{~s}^{-1}$ with a mean wind direction of $269.4^{\circ}$. The wind remained mainly westerly with some variation between northwesterly and southwesterly according to the eastwards displacement of the synoptic atmospheric features. The northerly or southerly meridional wind component is the main factor of the wind modulation on the turbulent heat fluxes: the southwards (northwards) wind brought subtropical warm and moist (polar cold and dry) air over colder (warmer) SST which considerably inhibits (enhances) the turbulent heat fluxes magnitude.

The MABL vertical mixing (induced by turbulence) is governed by both the vertical wind shear and the surface heat fluxes. The bulk Richardson number $\left(R_{\mathrm{ib}}\right)$ can be useful to identify which is the most efficient in the vertical turbulent mixing. It is the ratio of thermal (convective static stability) to mechanical (production/destruction) of turbulent kinetic energy. For instance, the rs1 profile above the STF performed during the supposed higher convective activity period at 16:21 UTC, exhibited an unstable profile with a large negative $R_{\mathrm{ib}}(-6.7)$ as well as a negative stability parameter (not shown). That indicated that the flow at the surface was mainly turbulent and unstable due to buoyancy and thermal effect rather than to a shear effect. The turbulent heat flux was enhanced by the southeasterly wind (weak for this region) with dry and cold air. This southeasterly wind thus destabilized the BL by enhanced the ocean to atmosphere flux. This is in agreement with the previous works about a cold and dry air mass destabilizing the $\mathrm{BL}$ at the front warm side when the wind flow is nearly perpendicular to the front (e.g., O'Neill et al., 2010). The opposite situation also occurred (rs11) for a neutral case where the boundary layer was well-mixed and with a large positive $R_{\mathrm{ib}}(+20)$, indicating that the turbulent mixing was mainly driven by the wind shear rather than by the buoyancy. That illustrates that, over these regions, the wind can directly inhibit or enhance the vertical mixing by the vertical shear profile.

It is also remarkable to classify the soundings in two categories whatever their geographical locations. The first one contains the soundings for which the SST exceeds the temperature of the air aloft (rs1, rs2, rs3, rs4, rs5, rs13, rs15, rs16, rs22, rs23, rs36) and the soundings for which the air temperature exceeds the SST (rs7, rs8, rs9, rs14, rs17, rs31, rs32) (refer to Fig. 2). It is not surprising that, for the former category, the MABL presents an unstable vertical profile covered by an inversion, mostly around $800 \mathrm{hPa}( \pm 50 \mathrm{hPa})$ (Fig. 3) and, for the latter category the MABL presents a near sta- ble profile which indicates that the vertical mixing is inhibited or completed with a significant vertical extend. But as mentioned before, the air-sea temperature gradient is mainly controlled by the wind direction associated with the synoptic system displacements.

\section{Conclusions}

The Southern Hemisphere south of South Africa has received little attention in regard to air-sea interaction, most likely due to paucity of measurements associated with harsh weather conditions. The measurements performed during the BONUS-GOODHOPE 2008 cruise provided a continuous sampling of the atmospheric state close to the ocean surface (from $34.4^{\circ} \mathrm{S} / 15.9^{\circ} \mathrm{E}$ to $57.55^{\circ} \mathrm{S} / 00^{\circ} \mathrm{E}$ ) as well as vertical samplings of the atmosphere where the radiosondes were released regularly and/or over remarkable oceanic features (fronts, eddies). Additionally, the in-situ atmospheric data permitted a derivation of the turbulent heat flux and the heat balance at the surface by also considering the measured radiation terms. To the author's knowledge, it is the first time that such atmospheric measurements have been conducted along this north-south track that crossed major oceanic fronts from South Africa to $57^{\circ} \mathrm{S}$.

The joint analysis of this in-situ dataset and the ECMWF reanalysis for the determination of the synoptic conditions leads to the following conclusions:

- The STF, SAF and PF fronts encountered during the cruise exhibited some sharp SST gradients and it has been shown that the MABL vertical structure is subject to significant variability, especially over the warm side of the SST fronts with stabilization or destabilization according to the synoptic systems' eastward displacements.

- The thermal mixing processes occurred from the surface by the turbulent heat fluxes transfers, while the mechanical processes due to wind shear were able to mix within the entire BL. However, the former process was also partly controlled by the dynamics. It has been shown that, south of the STF, the meridional component of the wind drove the stability variability of the MABL by an enhancement or an inhibition of the surface thermal processes and the wind shear. Since the SST gradient and the sharp SST front were North-South organized, and since the zonal wind component was mainly westerly: (i) a northerly meridional wind component induced a stabilization of the MABL over the warm side of the front and, (ii) a southerly meridional wind component induced a destabilization of the MABL over the warm side of the front

- The direct impact of the warm eddy on the MABL has been shown in terms of thermodynamic effects 
mainly through the turbulent heat fluxes. Some dynamics effects were suspected (anticyclonic wind direction change above the eddy centre - the warmer SST) but a higher spatial resolution sampling is required to demonstrate this actual effect of the eddy. The lack of information about the synoptic situation at the exact time of measurements complicates the analysis and does not permit to discriminate whether or not the eddy impacts mainly the atmospheric surface dynamics aloft. Moreover, the mesoscale oceanic turbulence (here as a form of eddies) significantly increases the release of heat in the atmosphere mainly via the LHF, particularly during the night.

- The diurnal cycle was not marked enough to represent an important cause of the MABL vertical mixing variability.

Finally, the wind changes (associated with the eastward displacement of synoptic features) induced northerly (southerly) advection of warm (cold) and moist (dry) air above colder (warmer) oceanic regions with a high SST gradient. The result was a decrease (increase) of the turbulent heat flux above these SST discontinuities, stabilizing (destabilizing) the MABL just above. Additionally, according to the vertical wind shear profile and the wind intensity, these processes can be enhanced or inhibited.

One can note that during that summer, the latent heat flux was mainly released from ocean to atmosphere. The ocean mainly lost heat through evaporative turbulent processes, which are highly dependent on wind velocity. However, it cannot be concluded that the phenomena is amplified during the winter season. Walker and De Mey (1988) indeed showed that turbulent heat flux displays little seasonality over the Agulhas retroflexion region. The main reason is persistent westerly and southwesterly wind flow throughout the year which ensures that cold/dry air repeatedly forces loss of ocean heat. As a consequence, once an SST anomaly is identified and persistent, investigating the frequencies, the intensities and particularly the meridional wind component occurrences can bring relevant information for quantifying the loss of ocean heat from South African continent to the ACC.

The dataset recorded during the BGH cruise also present interest for other studies (atmospheric reanalysis assessment, air-sea processes over the Southern Ocean, etc.) and has been used to validate two satellite datasets: the twice-daily QuikSCAT winds and the daily OAflux dataset of latent and sensible heat fluxes, as well as numerical weather forecasts performed during the cruise with the WRF model over the Southern Ocean (Messager and Faure, 2012).

Acknowledgements. Authors are thankful to the officers and crew of the R/V Marion Dufresne, for their precious help and cooperation, and to all other contributors to the numerous measurements used in the article. The IPY/BONUS-GoodHope and CLIVAR/GoodHope projects received support from the Institut National des Sciences de l'Univers (INSU), the CNRS, the IFREMER program "Circulation Océanique", the French Polar Institute Paul Emile Victor (IPEV), the University of Brest (UBO-IUEM), and the Agence Nationale de la Recherche (ANR). (ANR-07-BLAN-0146-01). The LOS-IFREMER is also thanked for the funds provided for the radiosoundings.

Edited by: F. Dehairs

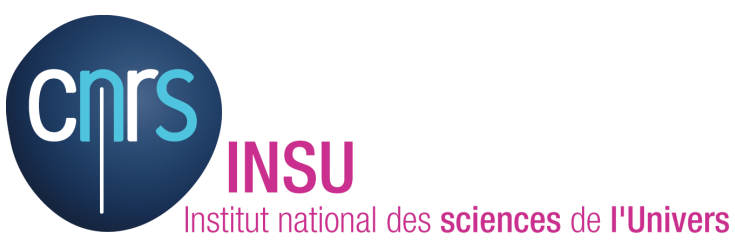

The publication of this article is financed by CNRS-INSU.

\section{References}

Ansorge, I., Speich, S., Lutjeharms, J., Goni, G., Rautenbach, H., Froneman, W., Garzoli, S., and Arhan, M.: Monitoring the oceanic flow between Africa and Antarctica : Report of the first GoodHope cruise, J. African Science, 2004.

Arhan, M., Speich, S., Messager, C., Dencausse, G., Fine, R., and Boye, M.: Anticyclonic and cyclonic eddies of subtropical origin in the subantarctic zone south of Africa, J. Geophys. Res., 116, C11004, doi:10.1029/2011JC007140, 2011.

Belkin, I. M. and Gordon, A. L.: Southern Ocean fronts from the Greenwich meridian to Tasmania, J. Geophys. Res., 101, 36753696, 1996.

Boebel, O., Lutjeharms, J., Schmid, C., Zenke, W., Rossby, T., and Barron, C.: The Cape Cauldron: a regime of turbulent inter-ocean exchange, Deep-Sea Res. II, 50, 57-86, 2003.

Bourras, D., Reverdin, G., Giordani, H., and Caniaux, G.: Response of the atmospheric boundary layer to a mesoscale oceanic eddy in the northeast Atlantic, J. Geophys. Res., 109, doi:10.1029/2004JD004799, 2004.

Branellec, P., Arhan, M., and Speich, S.: Projet GoodHope: Campagne BONUS/GOODHOPE-Rapport de données CTD-O2, Ifremer internal report, Rep. OPS/LPO/10-02, 282 pp., Ifremer, Issy-les-Moulineaux, France, available at http://stockage.univ-brest.fr/ $\sim$ speich/BONUS_GoodHope/ gh08-rapp-hydroSM.pdf, 2010.

Bryden, H. L., Beal, L. M., and Duncan, L. M.: Structure and transport of the Agulhas Current and its temporal variability, J. Oceanogr., 61, 479-492, doi:10.1007/s10872-005-0057-8, 2005.

Businger, J. A. and Shaw, W. J.: The response of the marine boundary layer to mesoscale variations in sea-surface temperature, Dyn. Atmos. Oceans, 8, 267-281, 1984.

Chelton, D. B. and Xie, S.-P.: Coupled ocean-atmosphere interaction at oceanic mesoscales, Oceangr. Mag., 4, 52-69, 2010.

Chelton, D. B., Esbensen, S. K., Schlax, M. G., Thum, N., and Freilich, M. H.: Observations of coupling between surface wind stress and sea surface temperature in the eastern tropical Pacific, J. Climate, 14, 1479-1498, 2001.

Chelton, D. B., Schlax, M. G., Freilich, M. H., and Milliff, R. F.: Satellite measurements reveal persistent small-scale features in 
ocean winds, Science, 303, 978-983, 2004.

De Mey, R., Walker, N., and Jury, M.: Surface Heat Fluxes and Marine Boundary Layer Modification in the Agulhas Retroflection Region, J. Geophys. Res., 95, 15997-16015, 1990.

Dencausse, G., Arhan, M., and Speich, S.: Spatio-temporal characteristics of the Agulhas Current Retroflection, Deep Sea Res. Part 1, 57, 1392-1405, 2010.

De Ruijter, W. P. M., Biastoch, A., Drijfhout, S. S., Lutjeharms, J. R. E., Matano, R. P., Pichevin, T., Van Leeuwen, P. J., and Weijer, W.: Indian-Atlantic interocean exchange: Dynamics, estimation and impact, J. Geophys. Res., 104, 20885-20910, 1999.

Duncombe Rae, C. M.: Agulhas Retroflection Rings In the South Atlantic Ocean: An Overview, S. Afr. J. Mar. Sci., 11, 327-344, 1991.

Fairall, C. W., Bradley, E. F., Hare, J. E., Grachev, A. A., and Edson, J. B.: Bulk parameterization on air-sea fluxes: Updates and verification for the COARE algorithm, J. Climate, 16, 571-591, 2003.

Faure, V., Arhan, M., Speich, S., and Gladyshev, S.: Heat budget of the surface mixed layer south of Africa, Ocean Dynam., 61, 1441-1458, 2011.

Friehe, C. A., Shaw, W. J., Rogers, D. P., Davidson, K. L., Large, W. G., Stage, S. A., Crescenti, G. H., Khalsa, S. J. S., Greenhut, G. K., and Li, F.: Air-sea fluxes and surface layer turbulence around a sea-surface temperature front, J. Geophys. Res., 96, 8593-8609, 1991.

Giordani, H., Planton, S., Benech, B., and Kwon, B.-H.: Atmospheric boundary layer response to sea surface temperatures during the SEMAPHORE experiment, J. Geophys. Res., 103, 25047-25060, 1998.

Gladyshev, S., Arhan, M., Sokov, A., and Speich, S.: A hydrographic section from South Africa to the southern limit of the Antarctic Circumpolar Current at the Greenwich meridian, Deep Sea Res., 55, 1284-1303, 2008.

Gordon, A. L.: Indian-Atlantic transfer of thermocline water at the Agulhas retroflection, Science, 227, 1030-1033, 1985.

Jury, M. R.: A thermal front within the marine atmospheric boundary-layer over the Agulhas Current south of Africa: composite aircraft observations, J. Geophys. Res., 99, 3297-3304, 1994.

Jury, M. R. and Walker, N.: Marine boundary layer modification across the edge of the Agulhas Current, J. Geophys. Res., 93, 647-654, 1988.

Kelly, K. A., Small, R. J., Samelson, R. M., Qiu, B., Joyce, T. M., Kwon, Y. O., and Cronin, M. F.: Western boundary currents and frontal air-sea interaction: Gulf Stream and Kuroshio extension, J. Climate, 23, 5644-5667, 2010.

Kwon, B.-H., Bénech, B., Lambert, D., Durand, P., Druilhet, A., Giordani, H., and Planton, S.: Structure of the marine atmospheric boundary layer over an oceanic thermal front: SEMAPHORE experiment, J. Geophys. Res., 103, 2515925180, 1998.

Kwon, Y. O., Alexander, M. A., Bond, N. A., Frankignoul, C., Nakamura, H., Qiu, B., and Thompson, L. A.: Role of Gulf Stream and Kuroshio-Oyashio systems in large-scale atmosphere-ocean interaction: A review, J. Climate, 23, 32493281, 2010.

Lee-Thorp, A. M., Rouault, M., and Lutjeharms, J. R. E.: Moisture uptake in the boundary layer above the Agulhas Current: A case study, J. Geophys. Res., 104, 1423-1430, 1999.

Lutjeharms, J. R. E.: The exchange of water between the South Indian and South Atlantic Ocean, in: The South Atlantic: Present and Past Circulation, edited by: Wefer, G., Berger, W. H., Siedler, G., and Webb, D. J., Berlin (Springer-Verlag), 125-162, 1996.

Lutjeharms, J. R. E.: The Agulhas Current, Springer, Berlin, 2006.

Lutjeharms, J. R. E. and Gordon, A. L.: Shedding of an Agulhas ring observed at sea, Nature, 325, 138-140, 1987.

Lutjeharms, J. R. E. and Valentine, H. R.: Southern Ocean thermal fronts south of Africa, Deep-Sea Res., 31, 1461-1475, doi:10.1016/0198-0149(84)90082-7, 1984.

Lutjeharms, J. R. E. and Valentine, H. R.: Eddies at the Subtropical Convergence South of Africa, J. Phys. Oc., 18, 761-774, doi:10.1175/1520-0485(1988)018<0761:EATSCS > 2.0.CO;2, 1988.

Lutjeharms, J. R. E. and Van Ballegooyen, R. C.: The retroflexion of the Agulhas Current, J. Phys. Ocean, 18, 1570-1583, 1988.

Messager, C. and Faure, V.: Validation of remote sensing and weather model forecasts in the Agulhas ocean area to $57^{\circ} \mathrm{S}$ by ship observations, S. Afr. J. Sci., 108, 735, doi:10.4102/sajs.v108i3/4.735, 2012.

Minnett, P. J., Knuteson, R. O., Best, F. A., Osborne, B. J., Hanafin, J. A., and Brown, O. B.: The Marine-Atmosphere Emitted Radiance Interferometer (M-AERI), a high-accuracy, sea-going infrared spectroradiometer, J. Atmos. Oceanic Technol., 18, 9941013, 2001.

Morrow, R., Birol, F., Griffin, D., and Sudre, J.: Divergent pathways of cyclonic and anti-cyclonic ocean eddies, Geophys. Res. Lett., 31, L24311, doi:10.1029/2004GL020974, 2004.

O’Neill, L. W., Chelton, D. B., and Esbensen, S. K.: Observations of SST-induced perturbations of the wind stress field over the Southern Ocean on seasonal time scales, J. Climate, 16, 23402354, 2003.

O’Neill, L. W., Chelton, D. B., and Esbensen, S. K.: HighResolution Satellite Measurements of the Atmospheric Boundary Layer Response to SST Variations along the Agulhas Return Current, J. Climate, 18, 2706-2723, 2005.

O’Neill, L. W., Chelton, D. B., and Esbensen, S. K.: The Effects of SST-Induced Surface Wind Speed and Direction Gradients on Midlatitude Surface Vorticity and Divergence, J. Climate, 23, 255-281, 2010.

Orsi, A. H., Nowlin Jr., W. D., and Whitworth III, T.: On the circulation and stratification of the Weddell Gyre, Deep-Sea Res. I, 40, 169-203, 1993.

Orsi, A. H., Whitworth III, T., and Nowlin, W. D.: On the meridional extent and fronts of the Antarctic Circumpolar Current, Deep-Sea Res. I, 42, 641-673, 1995.

Phillips, H. E. and Rintoul, S. R.: Eddy Variability and Energetics from Direct Current Measurements in the Antarctic Circumpolar Current South of Australia, J. Phys. Oc., 30, 3050-3076, doi:10.1175/1520-0485(2000)030<3050:EVAEFD>2.0.CO;2, 2000.

Reason, C. J. C.: Evidence for the influence of the Agulhas Current on regional atmospheric circulation patterns, J. Climate, 14, 2769-2778, 2001.

Rouault, M. and Lee-Thorp, A. M.: Fine-time resolution measurements of atmospheric boundary layer properties between Cape Town \& Marion Island, S. Afr. Mar. Sci., 17, 281-296, 1996. 
Rouault, M. and Lutjeharms, J. R. E.: Air-sea exchanges over an Agulhas eddy at the subtropical convergence, Global Atmos.Ocean Syst., 7, 125-150, 2000.

Rouault, M., Lee-Thorp, A. M., Ansorge, I., and Lutjeharms, J. R. E.: Agulhas Current Air-Sea Exchange Experiment, S. Afr. J. Sci., 91, 493-496, 1995.

Rouault, M., Lee-Thorp, A. M., and Lutjeharms, J. R. E.: Observations of the atmospheric boundary layer above the Agulhas Current during alongcurrent winds, J. Phys. 0c., 30, 70-85, 2000a.

Rouault, M., Lee-Thorp, A. M., and Lutjeharms, J. R. E.: The atmospheric Boundary Layer above the Agulhas Current during Alongcurrent Winds, J. Phys. 0c., 30, 40-50, 2000 b.

Schouten, M. W., de Ruijter, W. P. M., van Leeuwen, P. J., and Lutjeharms, J. R. E.: Translation, decay and splitting of Agulhas rings in the south-eastern Atlantic Ocean, J. Geophys. Res., 105, 21913-21925, 2000.

Small, R. J., DeSzoeke, S. P., Xie, S. P., O’Neill, L., Seo, H., Song, Q., Cornillon, P., Spall, M., and Minobe, S.: Air-sea interaction over ocean fronts and eddies, Dynamics of Atmospheres and Oceans, 45, 274-319, 2008.

Sokolov, S. and Rintoul, S. R.: Circumpolar structure and distribution of the Antarctic Circumpolar Current fronts: 1. Mean circumpolar paths, J. Geophys. Res., 114, C11018, doi:10.1029/2008JC005108, 2009a.

Sokolov, S. and Rintoul, S. R.: Circumpolar structure and distribution of the Antarctic Circumpolar Current fronts: 2. Variability and relationship to sea surface height, J. Geophys. Res., 114, C11019, doi:10.1029/2008JC005248, 2009b.

Song, Q., Cornillon, P., and Friehe, C. A.: Surface wind response to oceanic fronts, J. Geophys. Res. 111, C12006, doi:10.1029/2006JC003680, 2006.

Spall, M. A.: Midlatitude wind stress-sea surface temperature coupling in the vicinity of ocean fronts, J. Climate, 20, 3785-3801, 2007.
Speich, S. and Dehairs, F.: Cruise Report, MD 166 BONUSGOODHOPE, Internal Report, 246 pp., 2008.

Stammer, D.: On Eddy Characteristics, Eddy Transports, and Mean Flow Properties, J. Phys. Oc., 28, 727-739. doi:10.1175/15200485(1998)028<0727:OECETA > 2.0.CO;2, 1998.

Stull, R. B.: An introduction to boundary layer meteorology, Kluwer Academic Publishers, 1988.

Swart, S. and Speich, S.: An altimetry-based gravest empirical mode south of Africa: 2. Dynamic nature of the ACC fronts, J. Geophys. Res., 115, C03003, doi:10.1029/2009JC005300, 2010.

Swart, S., Speich, S., Ansorge, I., Goni, G., Gladyshev, S., and Lutjeharms, J.: Transport and variability of the antarctic circumpolar current South of Africa, J. Geophys. Res., 113, C09014, doi:10.1029/2007JC004223, 2008.

Tokinaga, H., Tanimoto, Y., and Xie, S.-P.: SST-induced surface wind variations over the Brazil-Malvinas Confluence: Satellite and in situ observations, J. Climate, 18, 3470-3482, 2005.

Tokinaga, H., Tanimoto, Y., Nonaka, M., Taguchi, B., Fukamachi, T., Xie, S.-P., Nakamura, H., Watanabe, T., and Yasuda, I.: Atmospheric sounding over the winter Kuroshio Extension: Effect of surface stability on atmospheric boundary layer structure, Geophys. Res. Lett., 33, L04703, doi:10.1029/2005GL025102, 2006.

Walker, M. and De Mey, R.: Ocean/atmosphere heat fluxes within the agulhas retroflection region, J. Geophys. Res., 93, 15473$15483,1988$.

Xie, S.-P.: Satellite observations of cool ocean-atmosphere interaction, B. Am. Meteorol. Soc., 85, 195-208, 2004.

Xie, S.-P., Ishiwatari, M., Hashizume, H., and Takeuchi, K.: Coupled ocean-atmosphere waves on the equatorial front, Geophys. Res. Lett., 25, 3863-3866, 1998. 